Supporting Information

\title{
Incorporation of Electron-Rich Indacenodithiophene Units into the Backbone of 2,6-Azulene-Based Conjugated Polymers for Proton-Responsive Materials and p-Type Polymeric Semiconductors
}

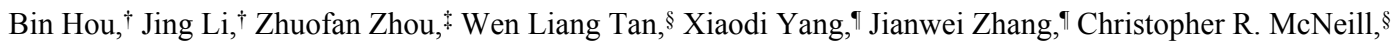
Congwu Ge, ${ }^{\dagger}$ Jingtao Wang, ${ }^{*,+}$ and Xike Gao*,†

$\dagger$ Key Laboratory of Synthetic and Self-Assembly Chemistry for Organic Functional Molecules, Shanghai Institute of Organic Chemistry, University of Chinese Academy of Sciences, Chinese Academy of Sciences, 345 Lingling Road, Shanghai 200032, China

$\$$ School of Chemical Engineering, Zhengzhou University, Zhengzhou 450001, China

$\S$ Department of Materials Science and Engineering, Monash University, Clayton, Victoria 3800, Australia

IInnovation Research Institute of Traditional Chinese Medicine, Shanghai University of Traditional Chinese Medicine, 1200 Cai Lun Road, Shanghai 201203, China

*E-mail: gaoxk@mail.sioc.ac.cn (XikeGao) 


\section{Table of contents}

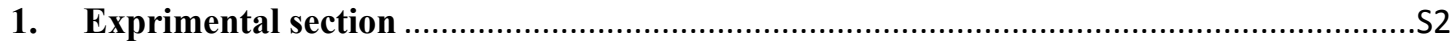

2. Model Stille coupling reaction for chemoselectivity …....................................................

3. High-temperature gel permeation chromatography (GPC) ........................................S5

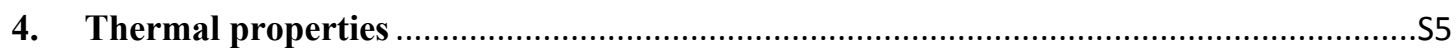

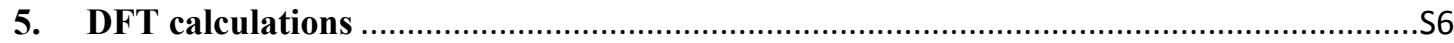

6. Color change, spectra change and reversibility of protonation ....................................

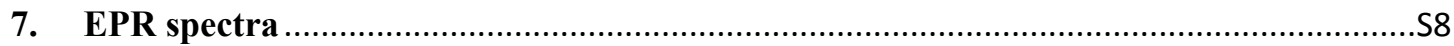

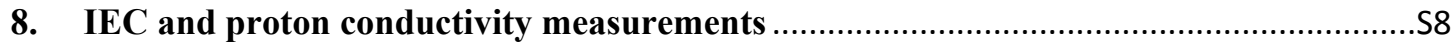

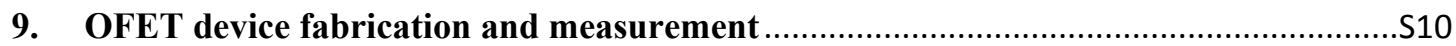

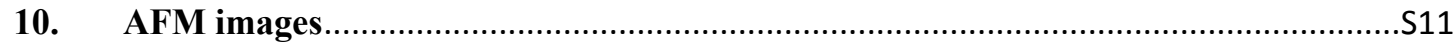

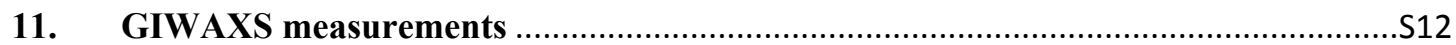

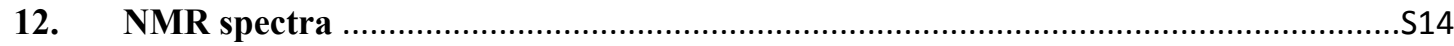

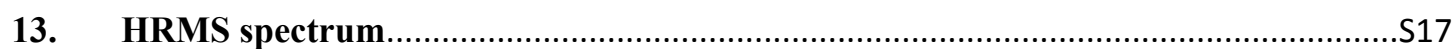

14. IR spectra

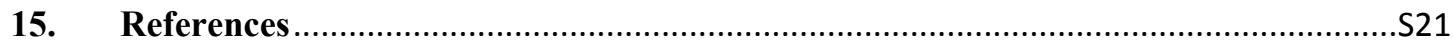




\section{Exprimental section}

General Information. Anhydrous toluene was dried over sodium and freshly distilled prior to use. 2,6-dibromoazulene 1 was prepared according to the reported literature. ${ }^{1-2}$ The distannylated IDT derivatives 2a-c were purchased from SunaTech Inc. Other commercially available reagents were used as received without further purification. NMR spectra ( ${ }^{1} \mathrm{H}$ NMR) were recorded on a Bruker NEO 600 or JEOL RESONANCE ECZ400S spectrometer. IR spectra were obtained on a NICOLET AVATAR 330 FT-IR spectrometer. Elemental analyses were performed on an ElementaVario EL III elemental analyzer. The high-temperature gel permeation chromatography (GPC) measurements were performed on a EcoSEC HLC-8321 GPC/HT instrument at $145^{\circ} \mathrm{C}$, using 1,2-dichlorobenzene as eluent and polystyrene as standards. Optical absorption spectra were measured on a UH4150 UVVis-NIR spectrophotometer. Thermogravimetric analysis (TGA) was performed on a TGA5500 analyzer under a dry nitrogen flow, heating from room temperature to $500{ }^{\circ} \mathrm{C}$ with a heating rate of $10{ }^{\circ} \mathrm{C} /$ min. Differential scanning calorimetry (DSC) was carried out on a DSC2500 instrument, heating from $-20^{\circ} \mathrm{C}$ to $300^{\circ} \mathrm{C}$ under a nitrogen atmosphere with a heating $/$ cooling rate of $10^{\circ} \mathrm{C} / \mathrm{min}$. Cyclic voltammetry (CV) was conducted on a CHI610D instrument at a scan rate of $100 \mathrm{mV} \mathrm{s}^{-1}$ with $\mathrm{Bu}_{4} \mathrm{NPF}_{6}(0.1 \mathrm{M})$ in $\mathrm{CH}_{2} \mathrm{Cl}_{2}$ as supporting electrolyte. A platinum button, a platinum wire, and a saturated calomel electrode (SCE) were used as the working, counter, and reference electrodes, respectively. The potentials were calibrated with the standard ferrocene/ferrocenium redox system $\left(\mathrm{Fc} / \mathrm{Fc}^{+}, E_{1 / 2}=0.39 \mathrm{~V}\right)$. Electron paramagnetic resonance $(\mathrm{EPR})$ was carried out on Bruker E500 10/12 instrument.

\section{$P(A z I D T-C 6)$}

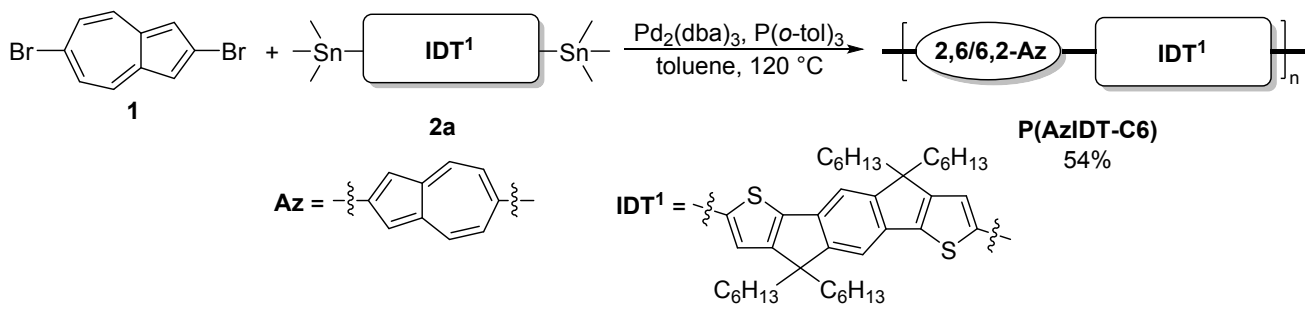

To a $100 \mathrm{ml}$ Schlenk tube were added 2,6-dibromoazulene 1 (172 mg, $0.6 \mathrm{mmol}), \mathrm{Pd}_{2}\left(\mathrm{dba}_{3}(28\right.$ $\mathrm{mg}, 0.03 \mathrm{mmol}), \mathrm{P}(\mathrm{o}-\mathrm{tol})_{3}(23 \mathrm{mg}, 0.075 \mathrm{mmol})$ and $2 \mathrm{a}(557 \mathrm{mg}, 0.6 \mathrm{mmol})$. The flask was evacuated and backfilled with nitrogen three times. $24 \mathrm{ml}$ toluene were then injected with syringe. The reaction vessel was sealed and heated at $120^{\circ} \mathrm{C}$ for $12 \mathrm{~h}$ with the color of solution from violet to blue. Then the mixture was quenched with saturated KF solution and the solution was dropped 
into methanol $(200 \mathrm{~mL})$ with the dark purple solid formed. After filtration, the residue was subjected to sequential Soxhlet extraction with methanol, acetone, hexane, dichloromethane and chloroform to remove the impurities and oligomers. The remaining polymers was extracted by chlorobenzene and then precipitation form methanol. The solid was filtered and dried under vacuum to give the metallic dark purple polymer (235 mg, 54\% yield). ${ }^{1} \mathrm{H}$ NMR (600 MHz, $\left.\mathrm{CD}_{2} \mathrm{Cl}_{4}\right): \delta$ see Figure $\mathrm{S} 15$. IR (KBr, thin film) $v\left(\mathrm{~cm}^{-1}\right): 3072,3004,2856,1574,1548,1524,1465,1407,1382,1334,1247$, $1173,1133,990,871,830,795,724,647,548$. GPC (o-DCB, Polystyrene standard, $\left.145^{\circ} \mathrm{C}\right): M_{\mathrm{n}}=$ $30.7 \mathrm{kDa}, \oslash=1.81$. Anal. Calcd for $\mathrm{C}_{74} \mathrm{H}_{80} \mathrm{~S}_{2}: \mathrm{C}, 82.36 ; \mathrm{H}, 8.85$. Found: $\mathrm{C}, 82.39 ; \mathrm{H}, 8.84$.

\section{P(AzIDT-PhC6)}

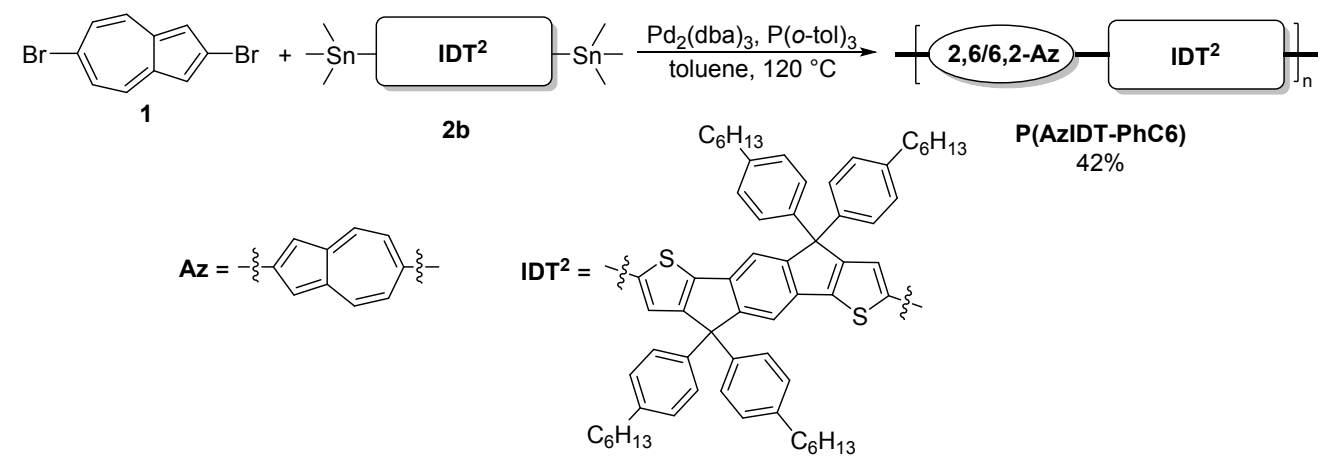

The synthetic method and purification procedure are similar with P(AzIDT-C6) with 2,6dibromoazulene $\mathbf{1}(86 \mathrm{mg}, 0.3 \mathrm{mmol})$ and $\mathbf{2 b}(370 \mathrm{mg}, 0.3 \mathrm{mmol})$. The metallic dark purple polymer was obtained from chloroform fraction (129 mg, $42 \%$ yield). ${ }^{1} \mathrm{H}$ NMR (600 MHz, $\left.\mathrm{CD}_{2} \mathrm{Cl}_{4}\right): \delta$ see Figure S16. IR (KBr, thin film) $v\left(\mathrm{~cm}^{-1}\right): 3021,2952,2922,2852,1571,1545,1508,1457,1405$, $1378,1355,1316,1247,1170,1120,1020,867,826,767,724,670,649,519$. GPC (o-DCB, Polystyrene standard, $145^{\circ} \mathrm{C}$ ): $M_{\mathrm{n}}=40.8 \mathrm{kDa}, \nexists=1.75$. Anal. Calcd for $\mathrm{C}_{50} \mathrm{H}_{64} \mathrm{~S}_{2}: \mathrm{C}, 85.99 ; \mathrm{H}$, 7.80. Found: C, 85.31; H, 7.84.

\section{P(AzIDTT-PhC6)}

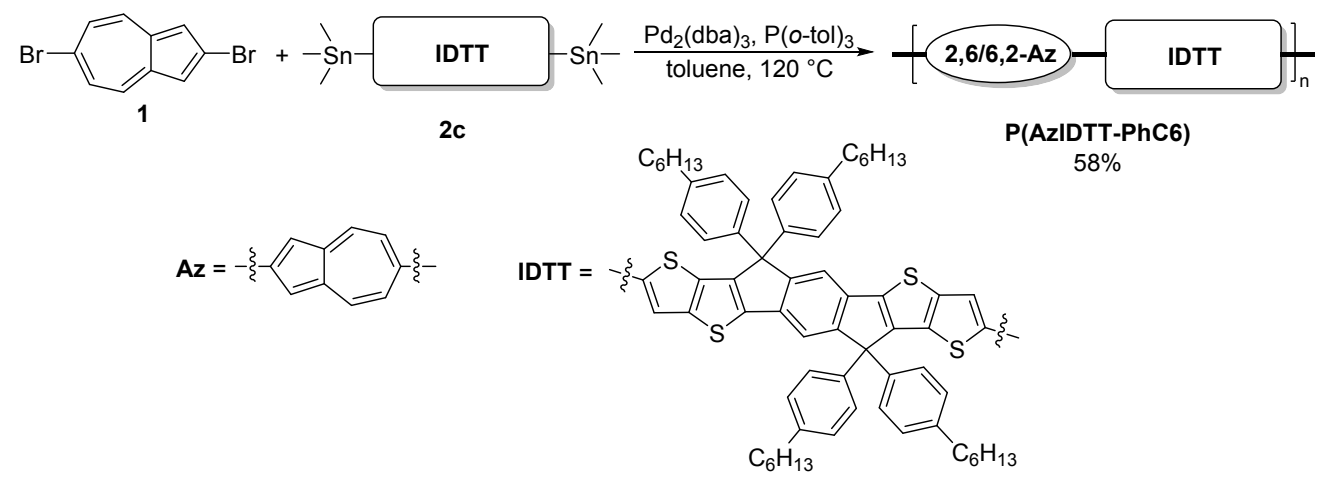


The synthetic method and purification procedure are similar with P(AzIDT-C6) with 2,6dibromoazulene $1(143 \mathrm{mg}, 0.5 \mathrm{mmol})$ and $2 \mathrm{c}(673 \mathrm{mg}, 0.5 \mathrm{mmol})$. The metallic dark purple polymer was obtained from chlorobenzene fraction $\left(332 \mathrm{mg}, 58 \%\right.$ yield). ${ }^{1} \mathrm{H}$ NMR (600 MHz, $\left.\mathrm{CD}_{2} \mathrm{Cl}_{4}\right): \delta$ see Figure S17. IR (KBr, thin film) $v\left(\mathrm{~cm}^{-1}\right): 3078,3021,2921,2851,1567,1544,1507$, $1462,1403,1362,1308,1275,1242,1184,1155,1120,1019,998,889,864,812,762,739,703$, $664,642,603,520,440,423$. GPC (o-DCB, Polystyrene standard, $\left.145{ }^{\circ} \mathrm{C}\right): M_{\mathrm{n}}=52.6 \mathrm{kDa}, \oslash=$ 1.98. Anal. Calcd for $\mathrm{C}_{78} \mathrm{H}_{80} \mathrm{~S}_{4}: \mathrm{C}, 81.77 ; \mathrm{H}, 7.04$. Found: $\mathrm{C}, 81.21 ; \mathrm{H}, 6.93$.

\section{Model Stille coupling reaction for chemoselectivity}

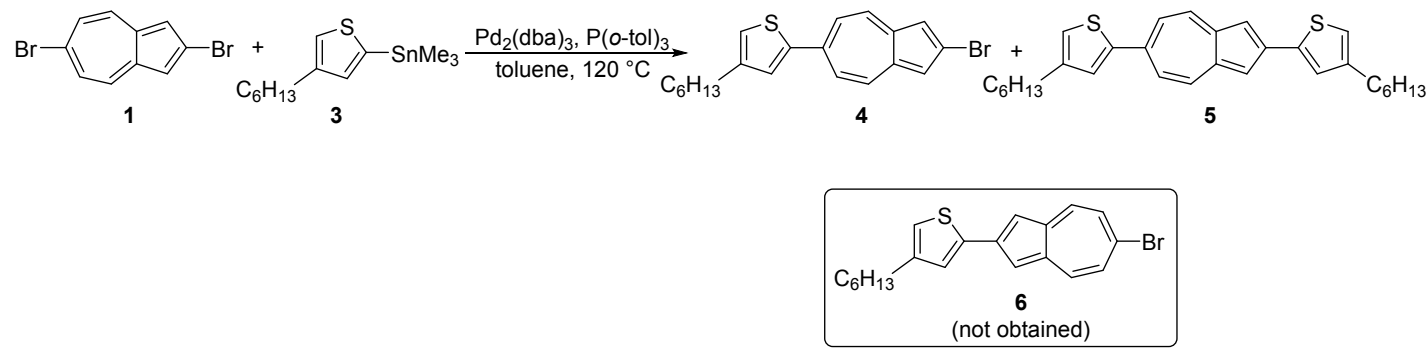

Scheme S1. Model Stille coupling reactions for chemoselectivity.

To a $25 \mathrm{ml}$ Schlenk tube were added 3 (50 mg, $0.15 \mathrm{mmol}$ ), 2,6-dibromoazulene 1 (42 mg, 0.15 $\mathrm{mmol}), \mathrm{Pd}_{2}(\mathrm{dba})_{3}(6.7 \mathrm{mg}, 0.0075 \mathrm{mmol})$ and $\mathrm{P}(o-\mathrm{tol})_{3}(5.6 \mathrm{mg}, 0.019 \mathrm{mmol})$. The flask was evacuated and backfilled with nitrogen three times. $6 \mathrm{ml}$ toluene were then injected with syringe. The reaction vessel was sealed and heated at $120^{\circ} \mathrm{C}$ for $9 \mathrm{~h}$. Then the mixture was quenched with saturated $\mathrm{KF}$ solution and extracted with $\mathrm{CH}_{2} \mathrm{Cl}_{2}$. The organic layer was dried over $\mathrm{Na}_{2} \mathrm{SO}_{4}$ and concentrated under vacuum. The residue was purified by flash column chromatography on silica gel $\left(\mathrm{PE} / \mathrm{CH}_{2} \mathrm{Cl}_{2}, V: V=5: 1\right)$ to afford the product $4(41 \mathrm{mg}, 73 \%)$ and $\mathbf{5}(8.1 \mathrm{mg}, 12 \%)$ as green solids. 4: $\mathrm{mp} 141-143^{\circ} \mathrm{C} .{ }^{1} \mathrm{H}$ NMR $\left(400 \mathrm{MHz}, \mathrm{CDCl}_{3}\right): \delta 8.18(\mathrm{~d}, J=10.8 \mathrm{~Hz}, 2 \mathrm{H}), 7.58(\mathrm{~d}, J=10.7 \mathrm{~Hz}$, 2H), $7.36(\mathrm{~d}, J=1.1 \mathrm{~Hz}, 1 \mathrm{H}), 7.28(\mathrm{~s}, 2 \mathrm{H}), 7.03(\mathrm{~s}, 1 \mathrm{H}), 2.64(\mathrm{t}, J=7.7 \mathrm{~Hz}, 2 \mathrm{H}), 1.67$ (p, $J=7.5$ $\mathrm{Hz}, 2 \mathrm{H}), 1.44-1.25(\mathrm{~m}, 6 \mathrm{H}), 0.90(\mathrm{t}, J=6.9 \mathrm{~Hz}, 3 \mathrm{H}) .{ }^{13} \mathrm{C} \mathrm{NMR}\left(100 \mathrm{MHz}, \mathrm{CDCl}_{3}\right): \delta 147.2,145.3$, 143.4, 138.6, 134.5, 127.8, 127.0, 122.9, 119.5, 31.8, 30.8, 30.6, 29.1, 22.8, 14.3. HRMS (ESI) $\mathrm{m} / \mathrm{z}$ : $[\mathrm{M}+\mathrm{H}]^{+}$calcd for $\mathrm{C}_{20} \mathrm{H}_{22} \mathrm{BrS}$ 373.0620; Found 373.0615. IR (KBr, thin film) $v\left(\mathrm{~cm}^{-1}\right): 3058,2956$, 2926, 2855, 1577, 1396, 1265, 829, 793, 739, 705, 594. 5: mp 150-152 ${ }^{\circ} \mathrm{C} .{ }^{1} \mathrm{H}$ NMR (400 MHz, $\left.\mathrm{CDCl}_{3}\right): \delta 8.13(\mathrm{~d}, J=10.6 \mathrm{~Hz}, 2 \mathrm{H}), 7.50(\mathrm{~d}, J=10.6 \mathrm{~Hz}, 2 \mathrm{H}), 7.45(\mathrm{~s}, 1 \mathrm{H}), 7.41(\mathrm{~s}, 1 \mathrm{H}), 7.33(\mathrm{~s}$, $1 \mathrm{H}), 6.99(\mathrm{~s}, 1 \mathrm{H}), 6.96(\mathrm{~s}, 1 \mathrm{H}), 2.69-2.59(\mathrm{~m}, 4 \mathrm{H}), 1.74-1.60(\mathrm{~m}, 4 \mathrm{H}), 1.43-1.27(\mathrm{~m}, 12 \mathrm{H}), 0.95$ -0.85 (m, 6H). ${ }^{13} \mathrm{C}$ NMR (100 MHz, $\left.\mathrm{CDCl}_{3}\right): \delta 147.7,145.0,144.8,143.4,141.8,140.7,140.1$, 134.4, 127.2, 127.0, 122.5, 122.2, 121.5, 114.7, 31.9, 31.8, 30.8, 30.7, 30.58, 30.56, 29.2, 22.8, 14.3. HRMS (ESI) $m / z$ : [M+H] calcd for $\mathrm{C}_{30} \mathrm{H}_{37} \mathrm{~S}_{2} 461.2331$; Found 461.2324. IR ( $\mathrm{KBr}$, thin film) $v\left(\mathrm{~cm}^{-}\right.$ 1): 2956, 2918, 2850, 1467, 1260, 1088, 1016, 839, 826, 800, 720 .
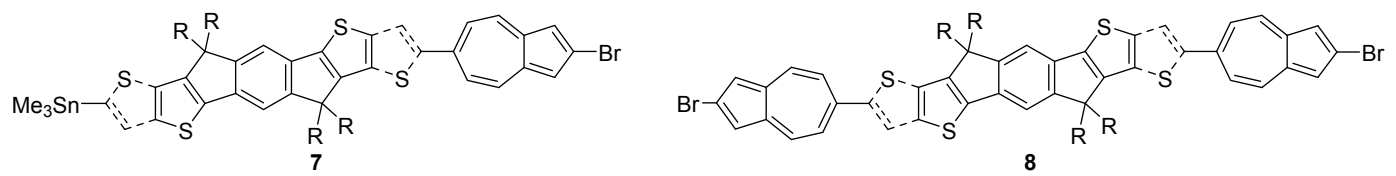

According to the model reaction, it can be deduced that two major products $\mathbf{7}$ and $\mathbf{8}$ might exist in 
the reaction system in the early stage of the polymeric reactions, and the orientation of 2,6-azulene units is regioregular in main chains of these three polymers, where both the head-to-head/tail-to-tail segments and head-to-tail ones might be included for azulene units.

\section{High-temperature gel permeation chromatography (GPC)}
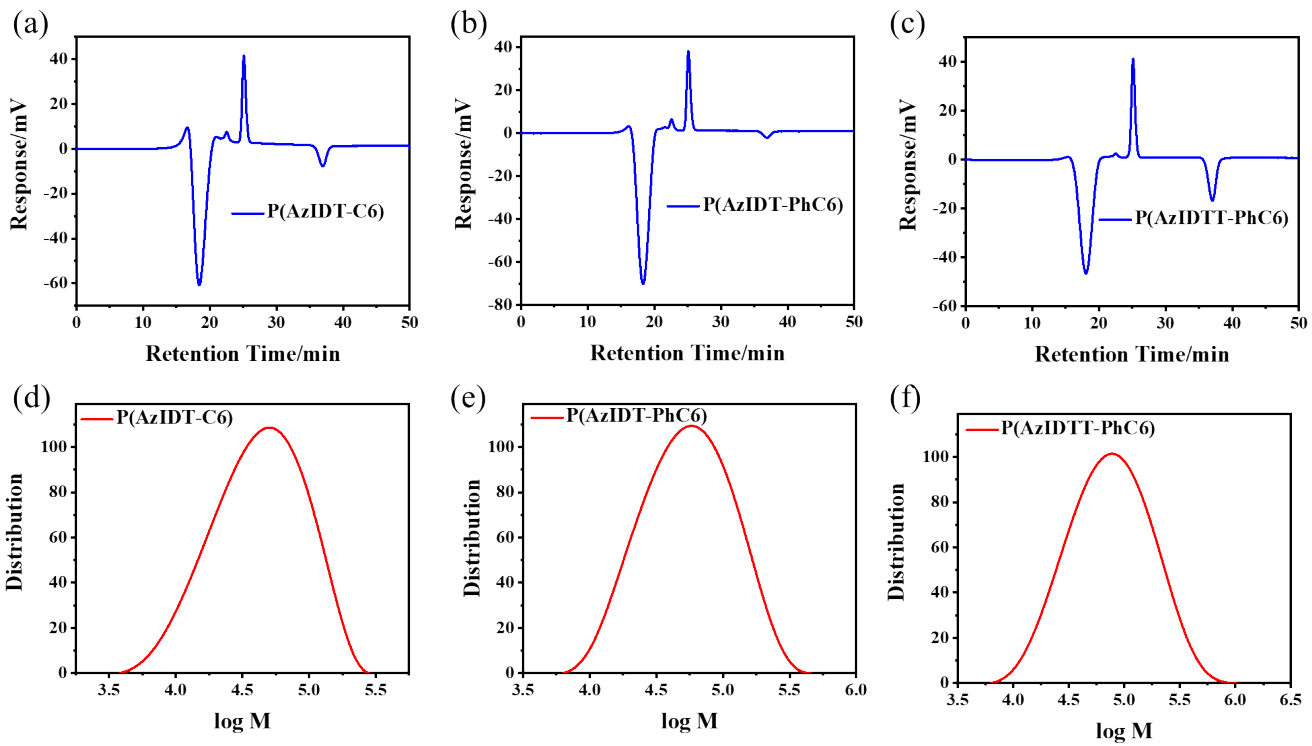

Figure S1. GPC curves of the polymers.

\section{Thermal properties}
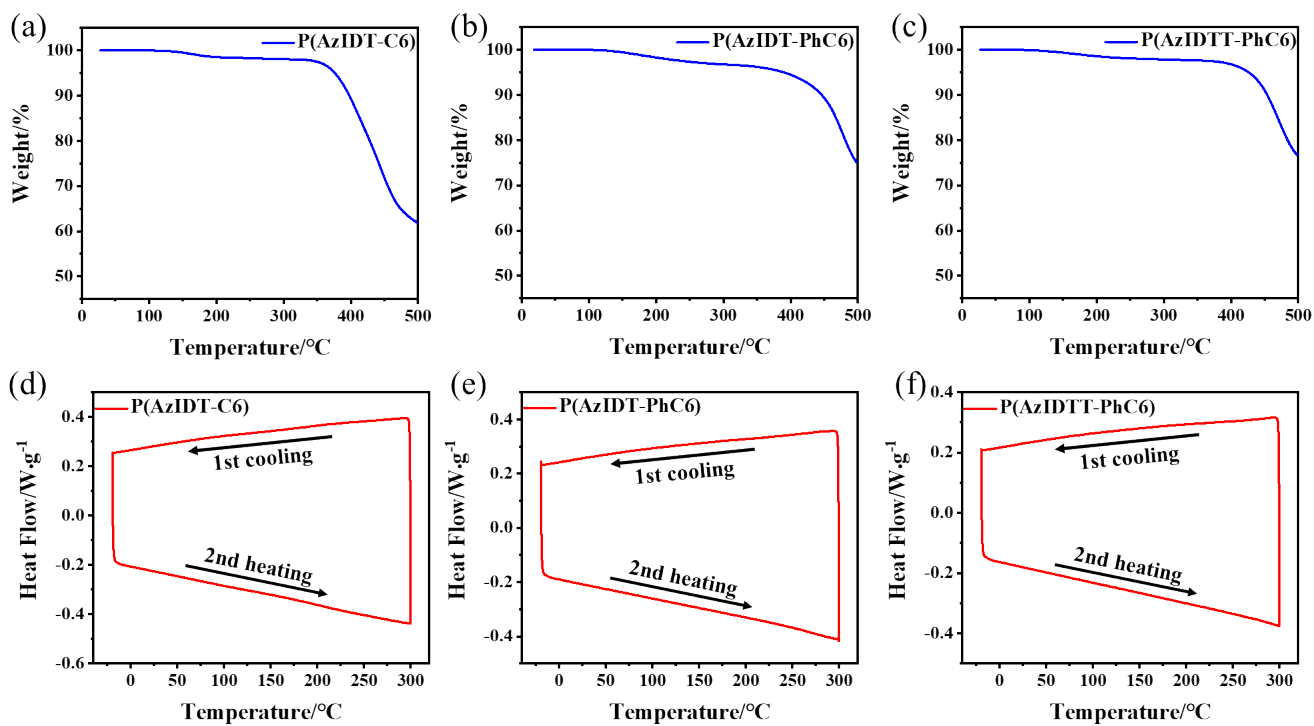

Figure S2. (a-c) TGA and (d-f) DSC curves of the polymers.

The 5\% weight loss temperature of P(AzIDT-C6), P(AzIDT-PhC6) and P(AzIDTT-PhC6) were 376,389 and $426{ }^{\circ} \mathrm{C}$, respectively. No endotherm or exotherm transition was observed in the differential scanning calorimetry (DSC) curves for the three polymers. 


\section{DFT calculations}
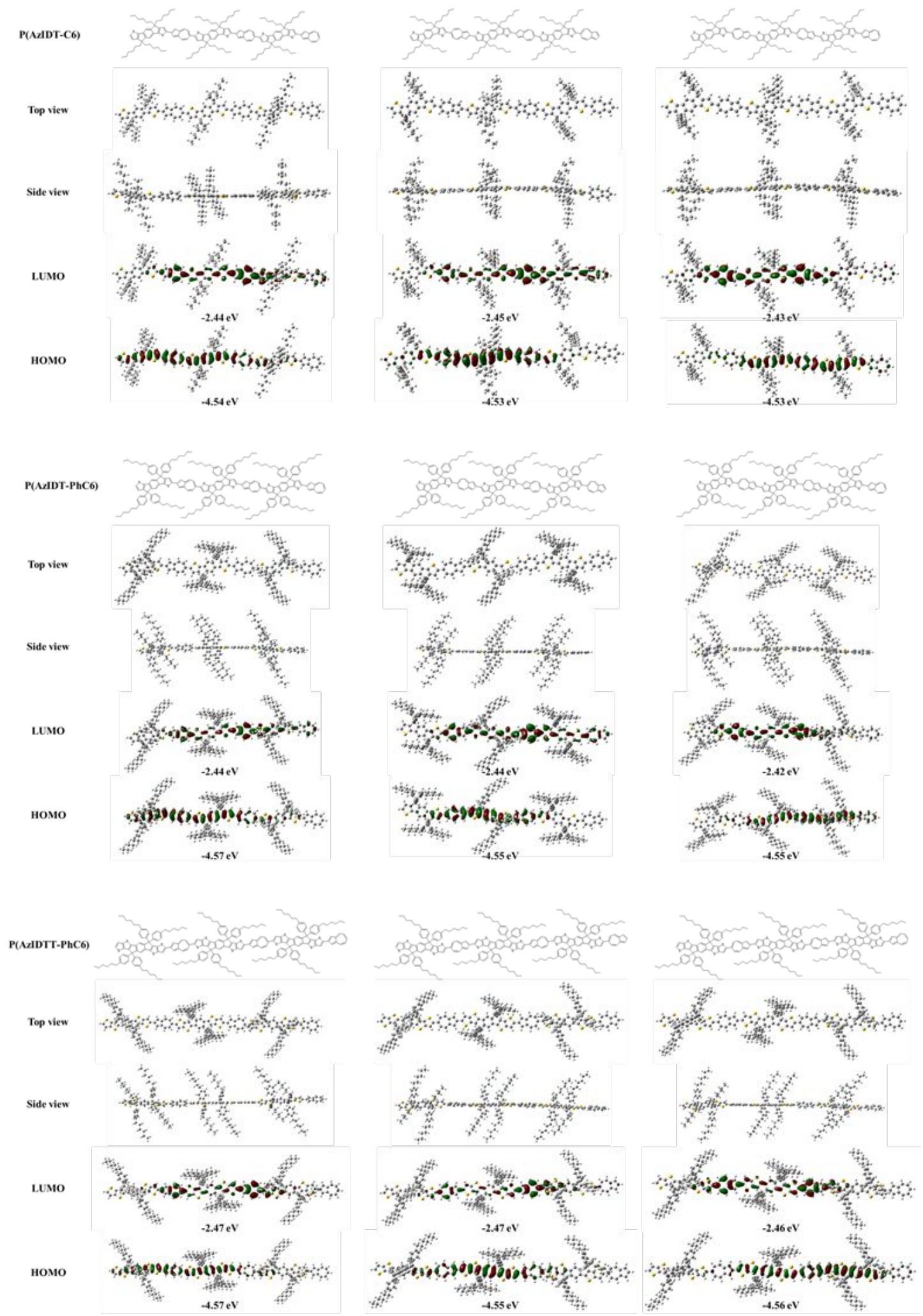

Figure S3. Optimized molecular structure, frontier molecular orbitals and energy levels of model molecules (trimer fragments) of the polymers obtained by DFT calculations.

All calculations were carried out at the B3LYP/6-31G(d,p) level using the Gaussian 16 program. ${ }^{3}$ To reduce the time required for calculations, three repeating units of the polymers were chosen as the model structures. 


\section{Color change, spectra change and reversibility of protonation}

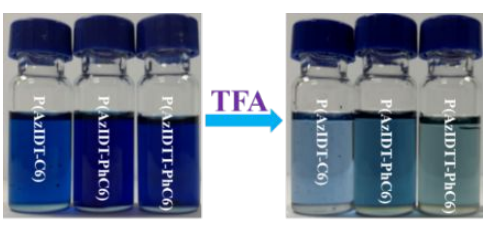

Figure S4. Color change of the polymers in chlorobenzene before and after adding TFA.
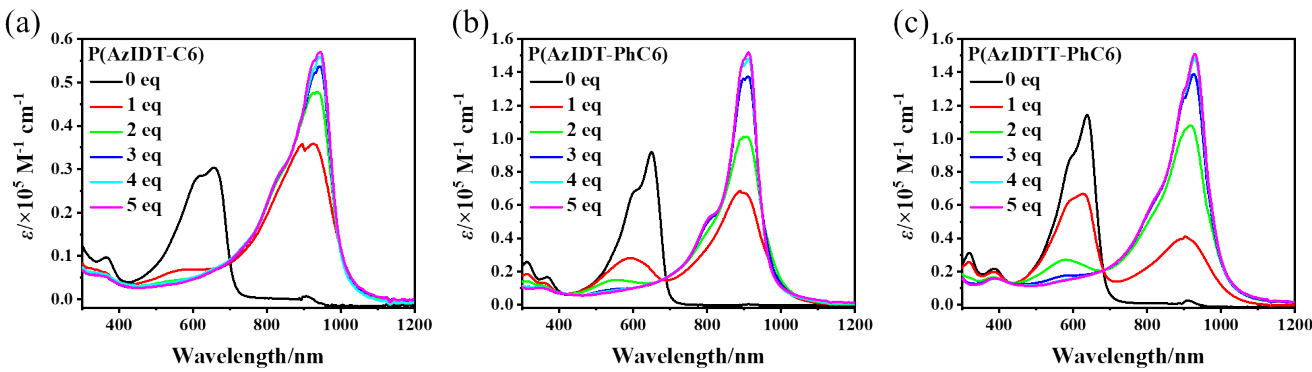

Figure S5. UV-Vis-NIR absorption spectra of the polymers in solution $\left(10^{-5} \mathrm{~mol} \mathrm{~L}^{-1}\right.$ in $1,2-$ dichlorobenzene) upon protonation with different equivalents of TFA.
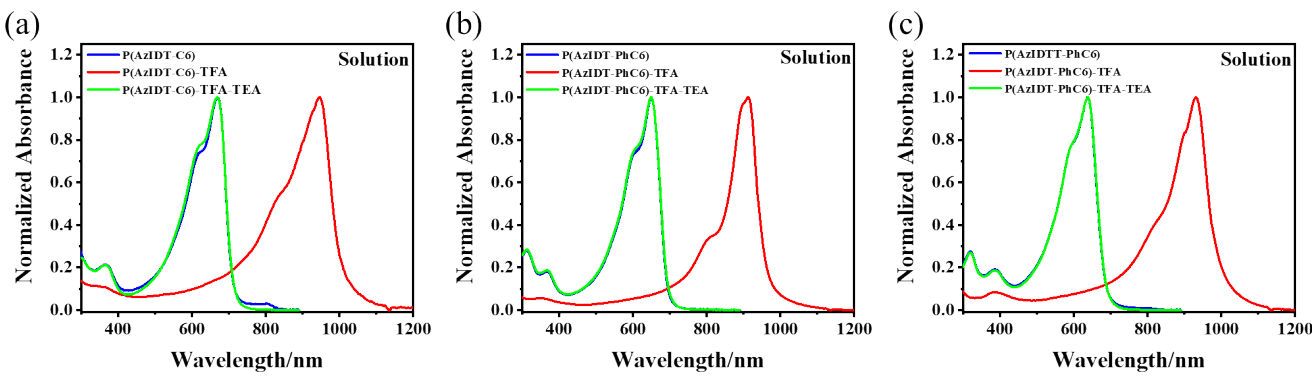

Figure S6. UV-vis-NIR absorption of the polymers in solution $\left(10^{-5} \mathrm{~mol} \mathrm{~L}^{-1}\right.$ in 1,2-dichlorobenzene) before protonation (blue), protonated with TFA (red) and neutralized by TEA (green).
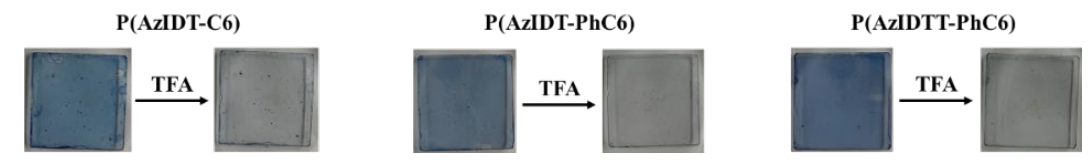

(a)

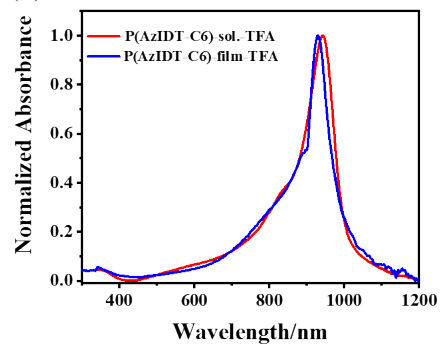

(b)

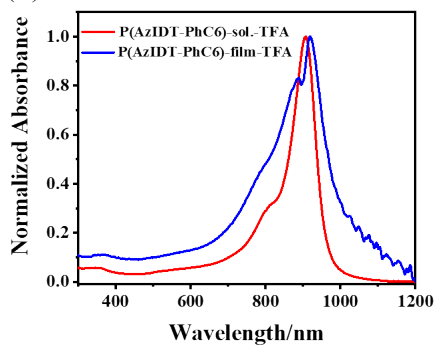

(c)

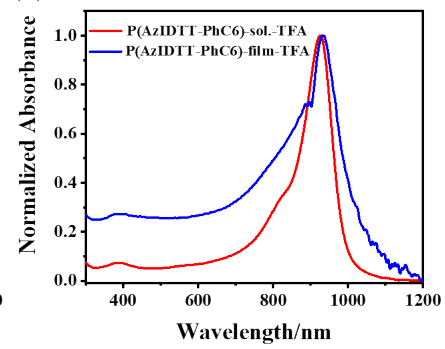

Figure S7. Color change of the polymers in thin film under TFA atmosphere (top) and UV-Vis-

NIR spectra of the polymers in solution and thin film upon protonation (bottom). 

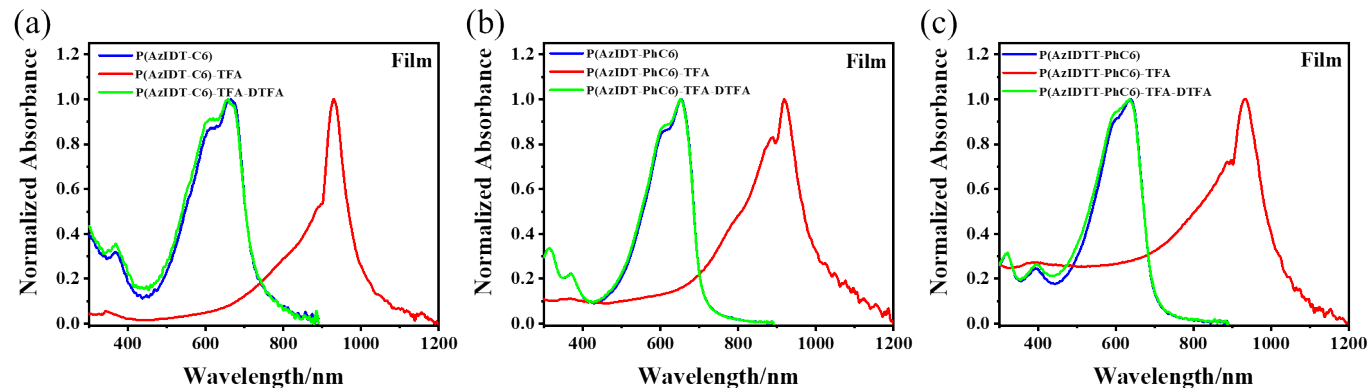

Figure S8. UV-vis-NIR absorption of the polymers in thin film before protonation (blue), protonated with TFA atmosphere (red) and then neutralized (green).

\section{EPR spectra}

(a)

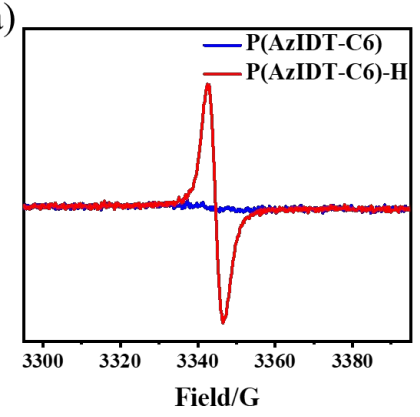

(b)

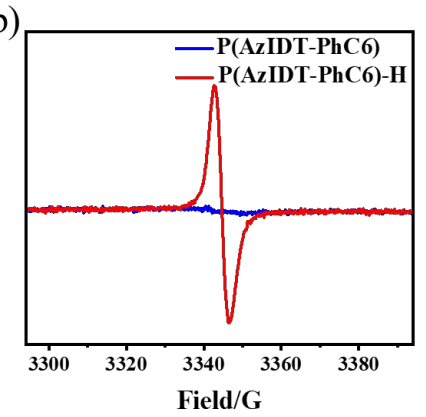

(c)

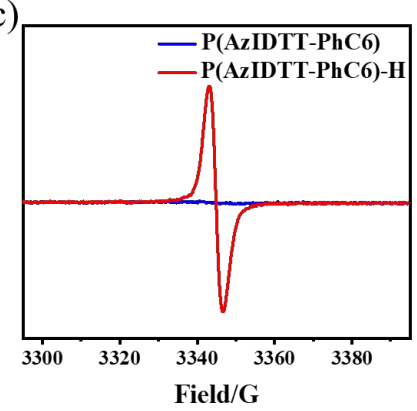

Figure S9. EPR spectra of the polymers in neutral and TFA-protonated state in 1,2-dichlorobenzene.

Table S1. Optical and EPR data of the polymers upon protonation

\begin{tabular}{cccccc}
\hline Polymer & $\lambda_{\max }{ }^{0 \mathrm{TFA} a} / \mathrm{nm}$ & $\lambda_{\max } 0.5 \% \mathrm{TFA} a / \mathrm{nm}$ & $\lambda_{\max }{ }^{\text {film } a} / \mathrm{nm}$ & $G^{b}$ & $\Delta H_{p p}{ }^{b} / \mathrm{G}$ \\
\hline P(AzIDT-C6) & 669 & 942 & 930 & 2.0023 & 4.00 \\
P(AzIDT-PhC6) & 650 & 907 & 919 & 2.0023 & 3.81 \\
P(AzIDTT-PhC6) & 637 & 926 & 933 & 2.0021 & 3.52 \\
\hline
\end{tabular}

${ }^{a}$ Obtained from UV-Vis-NIR spectra. ${ }^{b}$ Calculated from EPR spectra.

\section{IEC and proton conductivity measurements}

1) Preparation of Nafion and Nafion/P(AzIDTT-PhC6) membranes

Nafion and Nafion/P(AzIDTT-PhC6) membranes were fabricated by solution-casting method. Firstly, Nafion solution was heated in a vacuum-oven at $60{ }^{\circ} \mathrm{C}$ to remove the solvent and obtain dry Nafion resin. Then, the Nafion resin was redissolved in DMAC under stirring for $6 \mathrm{~h}$ to obtain a 5 wt.\% Nafion/DMAC solution. A certain of P(AzIDTT-PhC6) was dispersed in chloroform under ultrasonic for $4 \mathrm{~h}$, and then the dispersion solution was introduced to Nafion/DMAC solution under vigorous stirring and ultrasonic for 6 and $4 \mathrm{~h}$, respectively. The resultant mixture was cast onto a 
glass plate and dried in a vacuum-oven at $80{ }^{\circ} \mathrm{C}$ for $12 \mathrm{~h}$, and subsequently at $120^{\circ} \mathrm{C}$ for another 4 h. Finally, the membrane was peeled from the glass plate, and subjected to the sequential procedures of soaking in $3 \%(w / w) \mathrm{H}_{2} \mathrm{O}_{2}$ aqueous solution, rinsing with water, soaking in $1 \mathrm{M} \mathrm{H}_{2} \mathrm{SO}_{4}$, at $80{ }^{\circ} \mathrm{C}$ for $1 \mathrm{~h}$, respectively, and finally rinsing with water until neutral $\mathrm{pH}$ (There is no change observed in FT-IR for the power of P(AzIDTT-PhC6) under the same conditions (Figure S29), indicating the polymer kept the initial state.). The obtained membrane was designated as Nafion/P(AzIDTTPhC6), and the weight ratio of P(AzIDTT-PhC6) to Nafion is 3 wt.\% in this study. The recast Nafion control membrane was designated as Nafion.

2) Measurements of $I E C$ and proton conductivity

$I E C$ was measured by classical acid-base titration method. The dry membrane was immersed in $2 \mathrm{M} \mathrm{NaCl}$ solution at room temperature for $48 \mathrm{~h}$ to exchange $\mathrm{H}^{+}$with $\mathrm{Na}^{+}$. Then, the liberated $\mathrm{H}^{+}$ was titrated with $0.01 \mathrm{M} \mathrm{NaOH}$ solution, using phenolphthalein as indicator. The $I E C$ value was calculated by the equation:

$$
\operatorname{IEC}\left(\mathrm{mmol} \mathrm{g}^{-1}\right)=0.01 \times \frac{V_{N a O H}}{W_{d r y}}
$$

where $V_{\mathrm{NaOH}}(\mathrm{mL})$ is the consumed $\mathrm{NaOH}$ solution volume, $W_{d r y}$ is the weight of dry membrane. Proton conductivity was measured by AC impedance spectroscopy (ParStat MC 1000). The testing temperature and humidity were controlled by a membrane-testing device (MTS-740, Scribner Associates Inc.). The proton conductivity of the membrane was calculated by the equation:

$$
\sigma\left(\mathrm{mS} \mathrm{cm}^{-1}\right)=1000 \times \frac{l}{A R}
$$

where $l, A$, and $R$ are the thickness $(\mathrm{cm})$, testing area $\left(\mathrm{cm}^{2}\right)$ and resistance $(\Omega)$ of the membrane, respectively. 

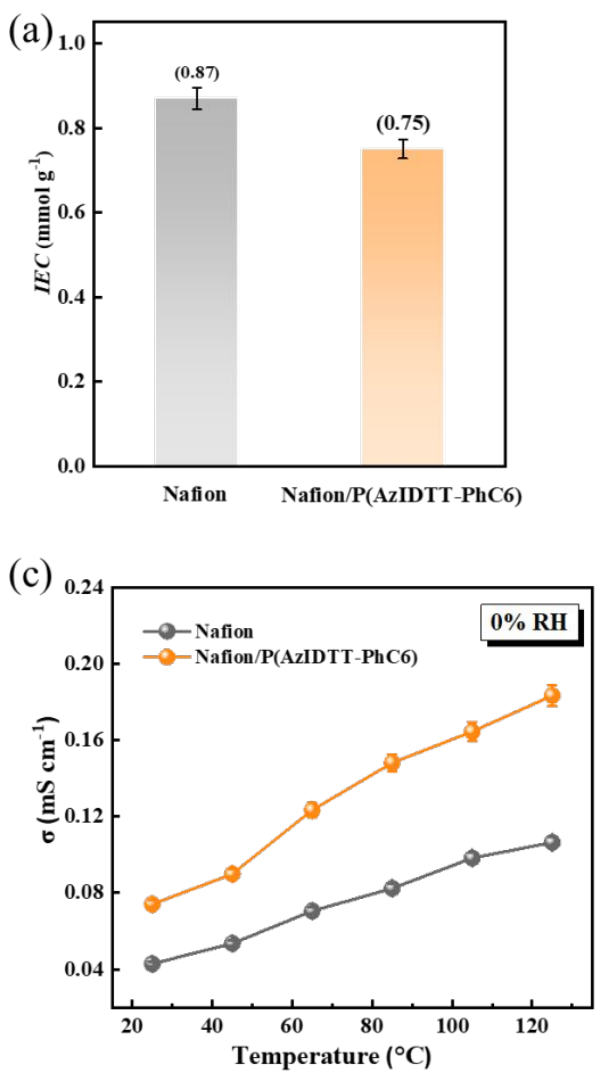

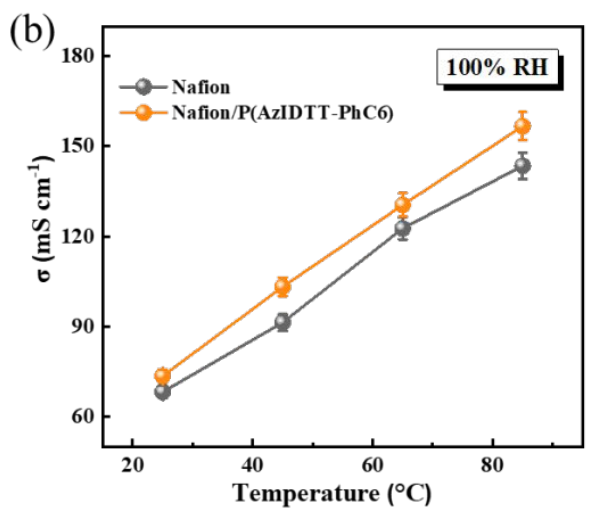

(d)

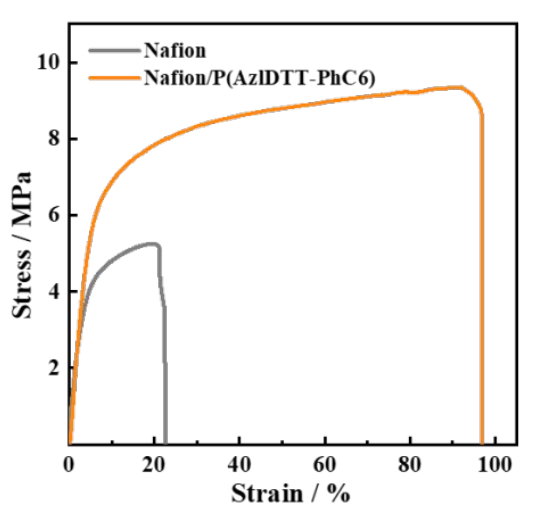

Figure S10. (a) IEC of Nafion and Nafion/P(AzIDTT-PhC6) membranes; (b) and (c) Proton conductivity of Nafion and Nafion/P(AzIDTT-PhC6) membranes at different temperature under $100 \%$ RH and 0\% RH atmosphere; (d) Mechanical properties of Nafion and Nafion/P(AzIDTT-PhC6) membranes.

\section{OFET device fabrication and measurement}

The OFET devices were fabricated on the $\mathrm{Si} / \mathrm{SiO}_{2}$ wafers modified by octadecyltrimethoxysilane (OTMS) using a bottom-gate/ top-contact (BGTC) configuration with a channel width of $273 \mu \mathrm{m}$ and a length of $31 \mu \mathrm{m}$. The $\mathrm{Si} / \mathrm{SiO}_{2}$ substrates were firstly cleaned by ultrasonication in deionized water, acetone, dichloromethane, chloroform, and isopropyl alcohol, and dried over quick purged $\mathrm{N}_{2}$. Octadecyltrimethoxysilane (OTMS) in trichloroethylene (3 mM) was spin-coated (20 s at 3000 rpm) onto the $\mathrm{Si} / \mathrm{SiO}_{2}$ substrates which were treated with UV/ozone for 20 min. A self-assembly monolayer was formed by storing the substrates in an ammonia chamber overnight. And then the substrates were successively cleaned by ultrasonication in acetone, toluene, and isopropyl alcohol, and finally dried with quick purged $\mathrm{N}_{2}$. The semiconductor films were spin-coated on the top of OTMS-treated $\mathrm{SiO}_{2}$ from their chlorobenzene solution $\left(5 \mathrm{mg} \mathrm{mL}^{-1}\right)$. Au was deposited on the top 
of the active layer through a shadow mask under high vacuum to be used as source and drain electrodes. The devices were measured using a Keithley 4200-SCS semiconductor analyzer in a glovebox with a nitrogen atmosphere.

Hole mobility $\left(\mu_{\mathrm{h}}\right)$ was calculated from the transfer curves in the saturated regime according to the following equation

$$
I_{\mathrm{D}}=(W / 2 L) \mu_{\mathrm{h}} C_{\mathrm{i}}\left(V_{\mathrm{G}}-V_{\mathrm{th}}\right)^{2}
$$

where $I_{\mathrm{D}}$ is the drain current, $C_{\mathrm{i}}$ is the capacitance of the dielectric layer, $V_{\mathrm{G}}$ is the gate voltage, and $V_{\text {th }}$ is the threshold potential.
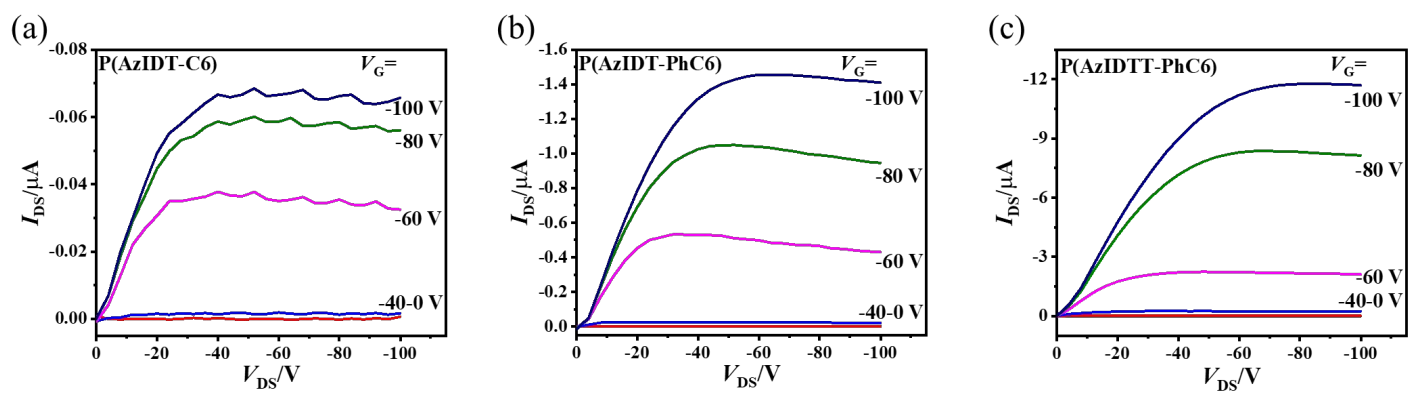

Figure S11. Typical output curves of the OFET devices based on the Polymers.

10. AFM images

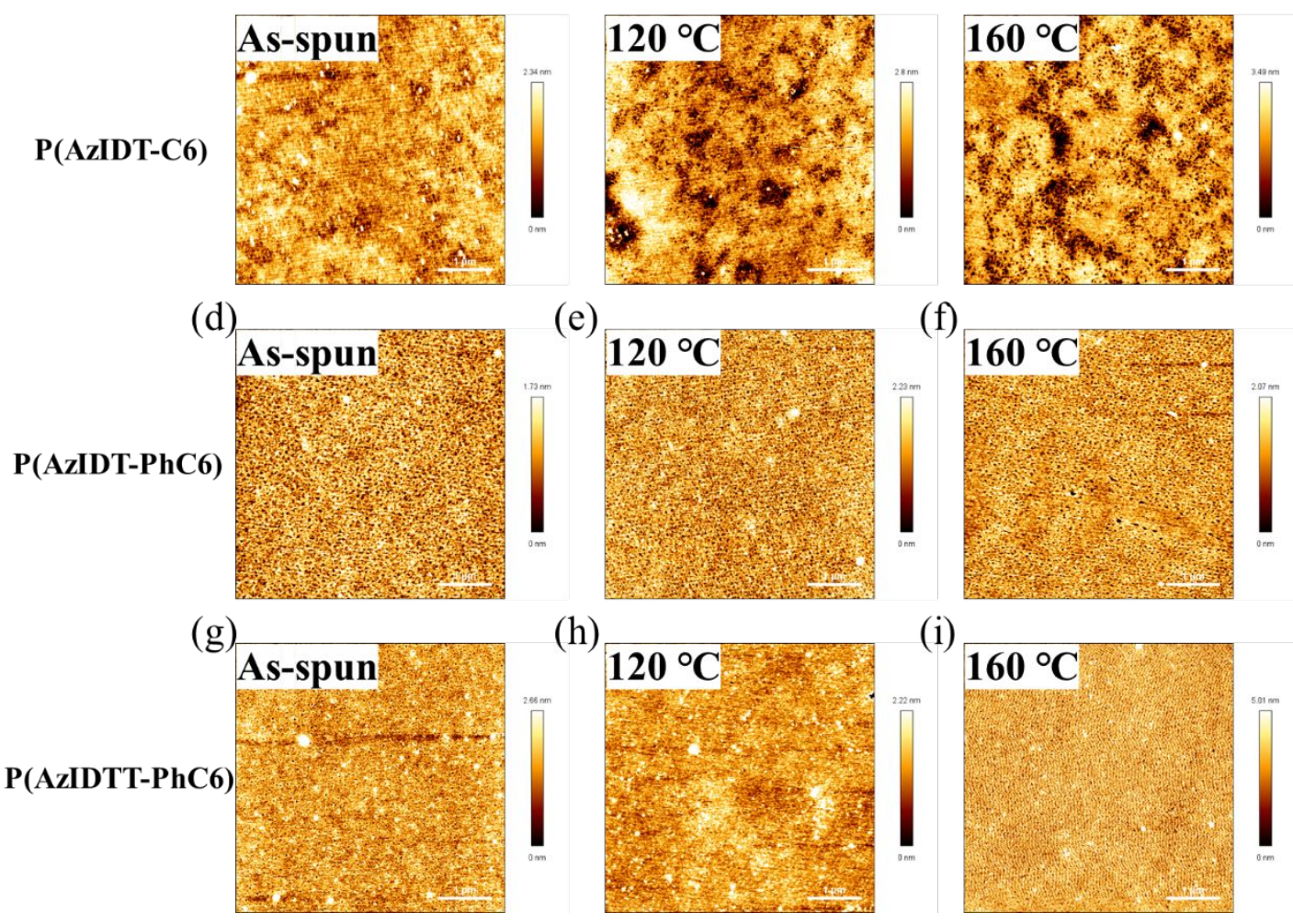

Figure S12. AFM height images of spin-coated thin films of the polymers annealed at different temperature. 


\section{GIWAXS measurements}

The grazing-incidence wide-angle X-ray scattering (GIWAXS) measurement was collected at the small and wide-angle X-ray scattering beamline at the Australian Synchrotron. ${ }^{4}$ An X-ray energy of $15.2 \mathrm{keV}$ was used, with the incident angle varied from $0.07^{\circ}$ to $0.12^{\circ}$ to identify the critical angle. Images and data reported correspond to the incident angle that maximized scattering intensity which was typically $\sim 0.10^{\circ}$. Scattering patterns were collected on a two-dimensional Dectris Pilatus3 $2 \mathrm{M}$ in-vacuum detector with pixel size of $0.172 \mathrm{~mm} \times 0.172 \mathrm{~mm}$ placed $628 \mathrm{~mm}$ downstream from the sample stage. The sample stage and detector and indeed the entire beam path was enclosed in a vacuum chamber to minimize background air scatter. An exposure of $1 \mathrm{~s}$ was used, with three $1 \mathrm{~s}$ exposures taken at different lateral offsets to cover the gaps between detector modules. These three exposure were combined to create a smooth $2 \mathrm{D}$ image. A fresh spot on the sample was used for each incident angle to prevent beam damage. GIWAXS data were processed using a modified version of the Nika package implemented within IgorPro. ${ }^{5}$ The GIWAXS patterns were corrected to real $Q_{\mathrm{z}}$ and $Q_{\mathrm{xy}}$ axes with the consideration of the missing wedge.

Table S2. GIWAXS data of the polymers

\begin{tabular}{ccccccc}
\hline \multirow{2}{*}{ Polymer } & \multicolumn{2}{c}{ Lamellar stacking } & \multicolumn{2}{c}{$\pi-\pi$ stacking } & \multicolumn{2}{c}{ Backbone repeat } \\
\cline { 2 - 7 } & $Q_{(100)} / \AA^{-1}$ & $d_{(100)} / \AA$ & $Q_{(010)} / \AA^{-1}$ & $d_{(010)} / \AA$ & $Q_{(001)} / \AA^{-1}$ & $d_{(001)} / \AA$ \\
\hline P(AzIDT-C6) & 0.520 & 12.1 & 1.473 & 4.3 & - & - \\
P(AzIDT-PhC6) & 0.386 & 16.3 & 1.457 & 4.3 & - & - \\
& & & & & & - \\
P(AzIDTT-PhC6) & 0.386 & 16.3 & 1.487 & 4.2 & 0.300 & 20.9 \\
\hline
\end{tabular}



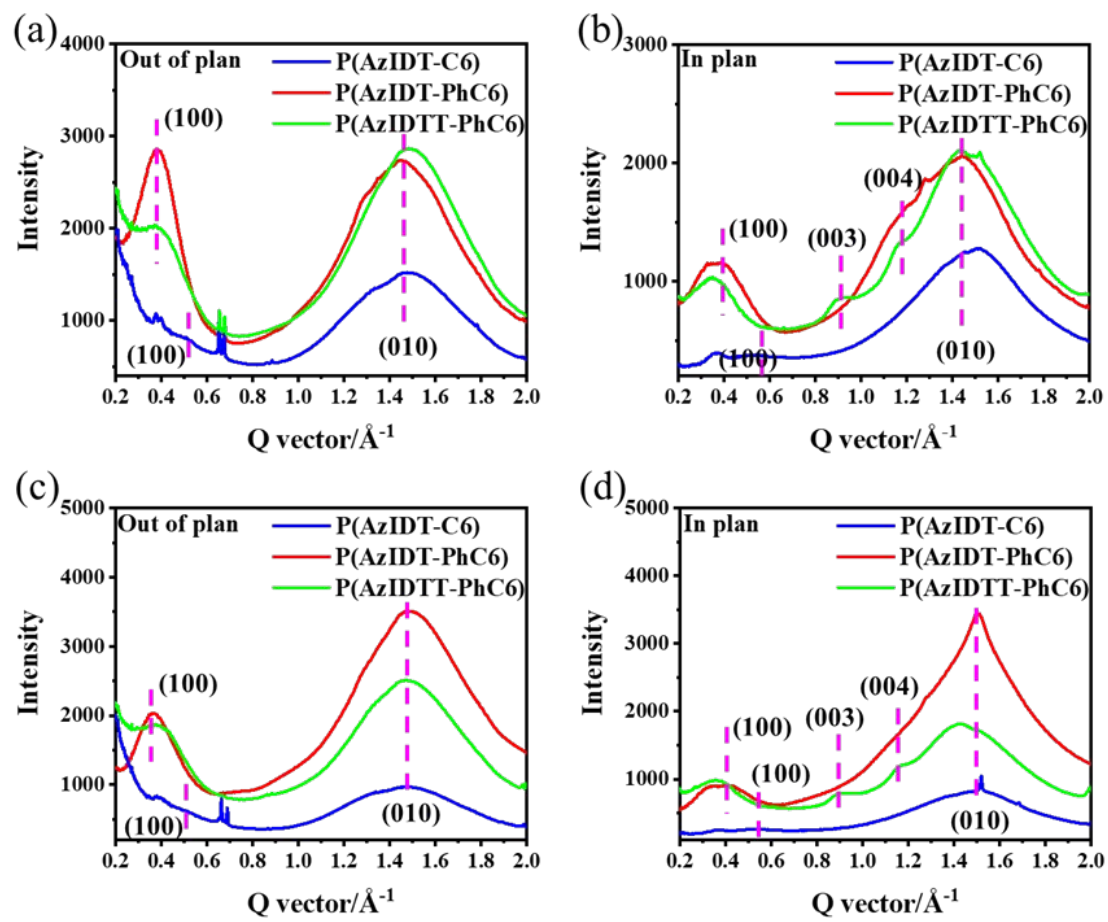

Figure S13. 1D GIXRD curves from 2D GIWAXS diffraction pattern. (a, b) As-spun films of P(AzIDT-C6), P(AzIDT-PhC6) and P(AzIDTT-PhC6); (c, d) Films of P(AzIDT-C6), P(AzIDTPhC6) and P(AzIDTT-PhC6) annealed at $160^{\circ} \mathrm{C}, 160^{\circ} \mathrm{C}$ and $120^{\circ} \mathrm{C}$, respectively.
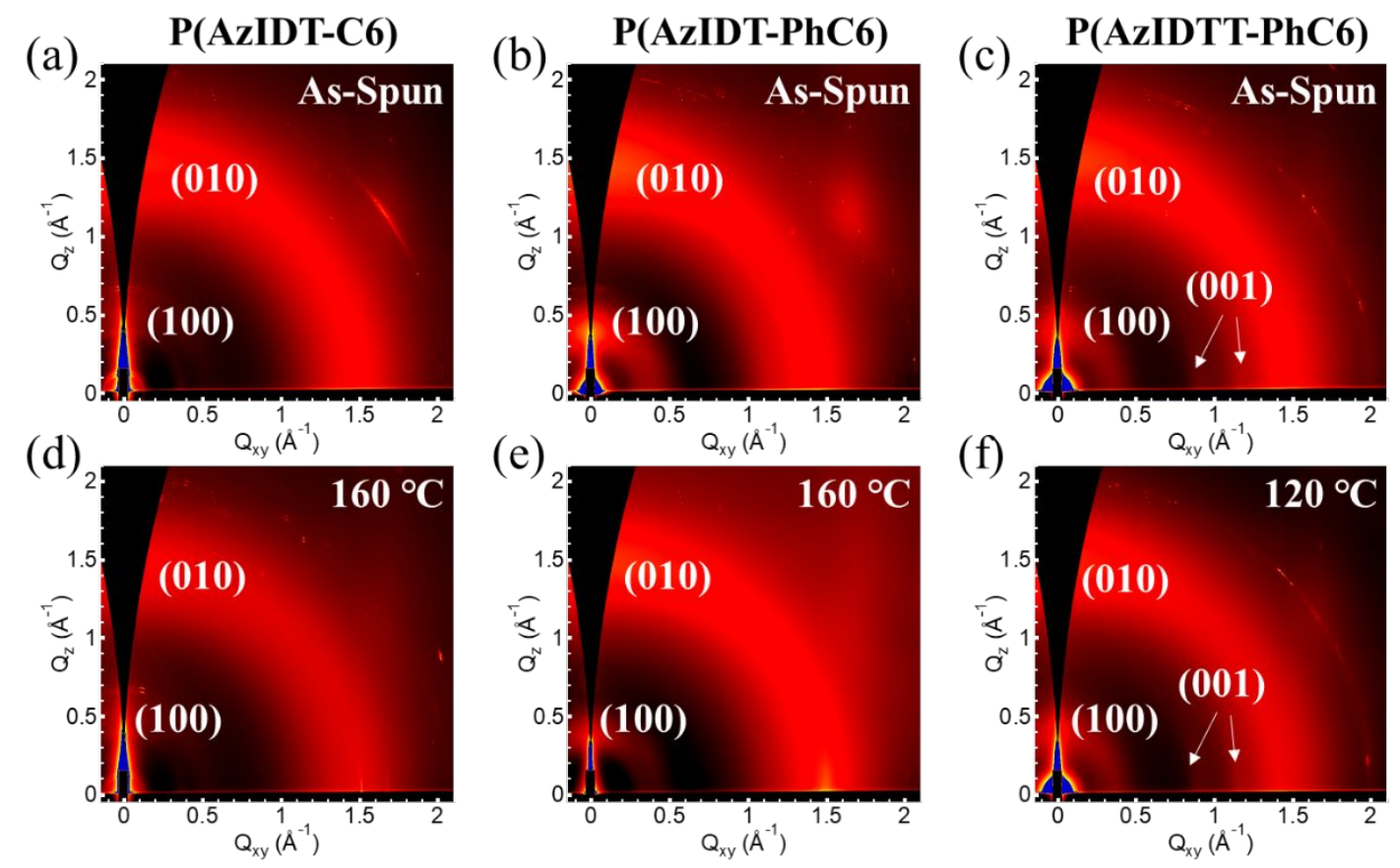

Figure S14. 2D GIWAXS patterns of the thin films of the polymers. All graphs are plotted in the identical intensity scale. 


\section{NMR spectra}

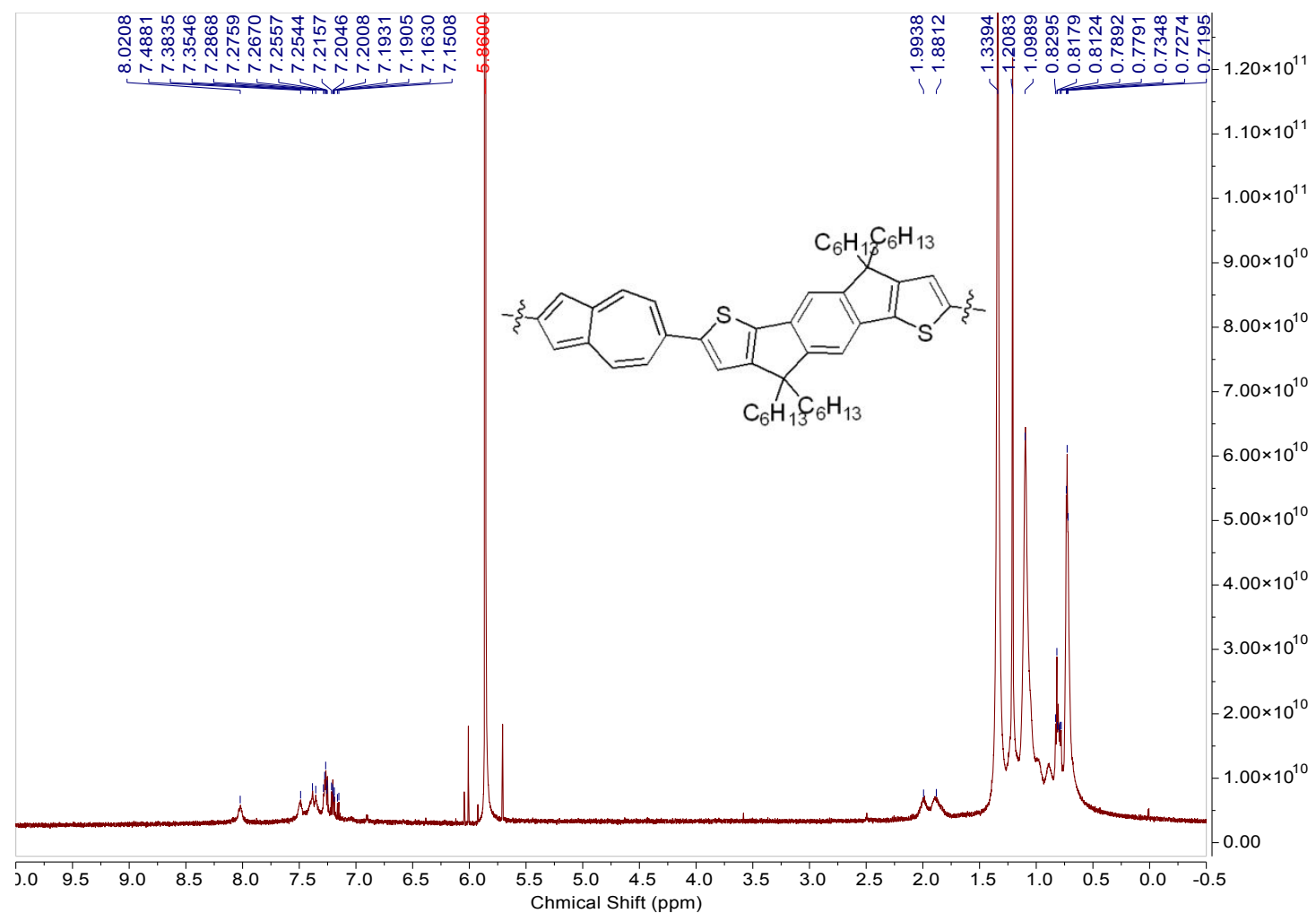

Figure S15. ${ }^{1} \mathrm{H}$ NMR spectrum of P(AzIDT-C6) $\left(\mathrm{C}_{2} \mathrm{D}_{2} \mathrm{Cl}_{4}, 100{ }^{\circ} \mathrm{C}\right)$

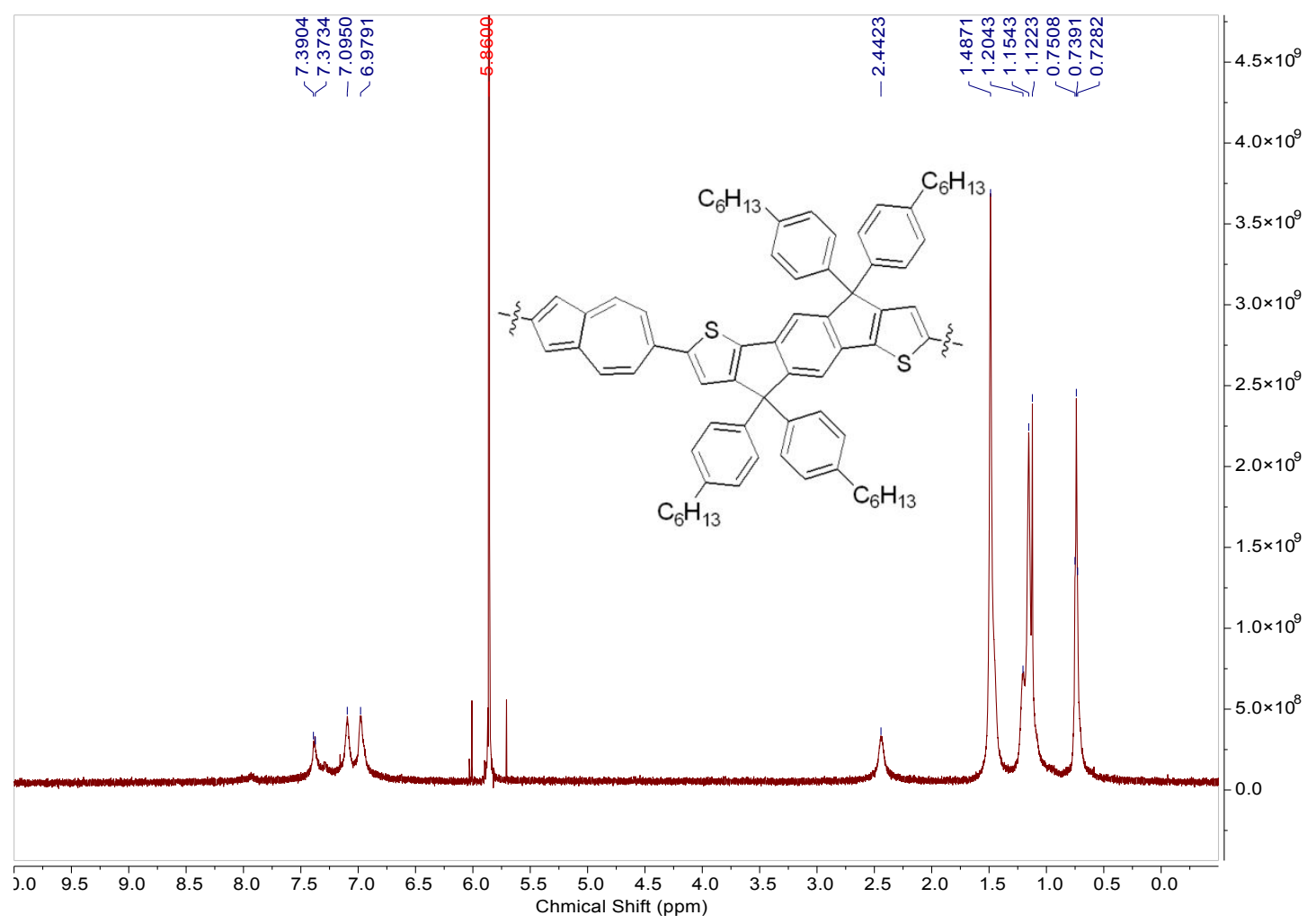

Figure S16. ${ }^{1} \mathrm{H}$ NMR spectrum of $\mathbf{P}\left(\right.$ AzIDT-PhC6) $\left(\mathrm{C}_{2} \mathrm{D}_{2} \mathrm{Cl}_{4}, 100{ }^{\circ} \mathrm{C}\right)$ 


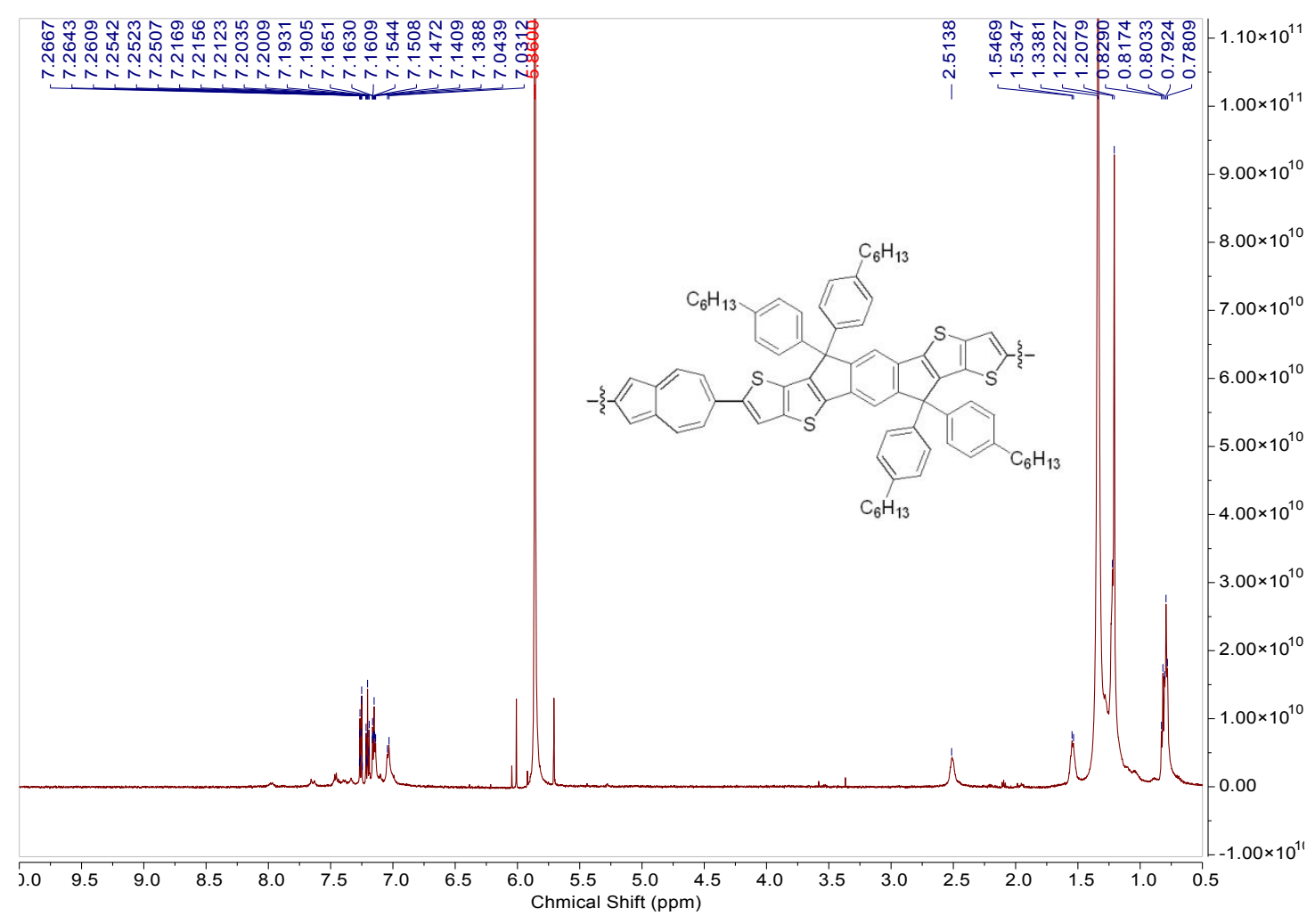

Figure S17. ${ }^{1} \mathrm{H}$ NMR spectrum of P(AzIDTT-PhC6) $\left(\mathrm{C}_{2} \mathrm{D}_{2} \mathrm{Cl}_{4}, 100{ }^{\circ} \mathrm{C}\right)$

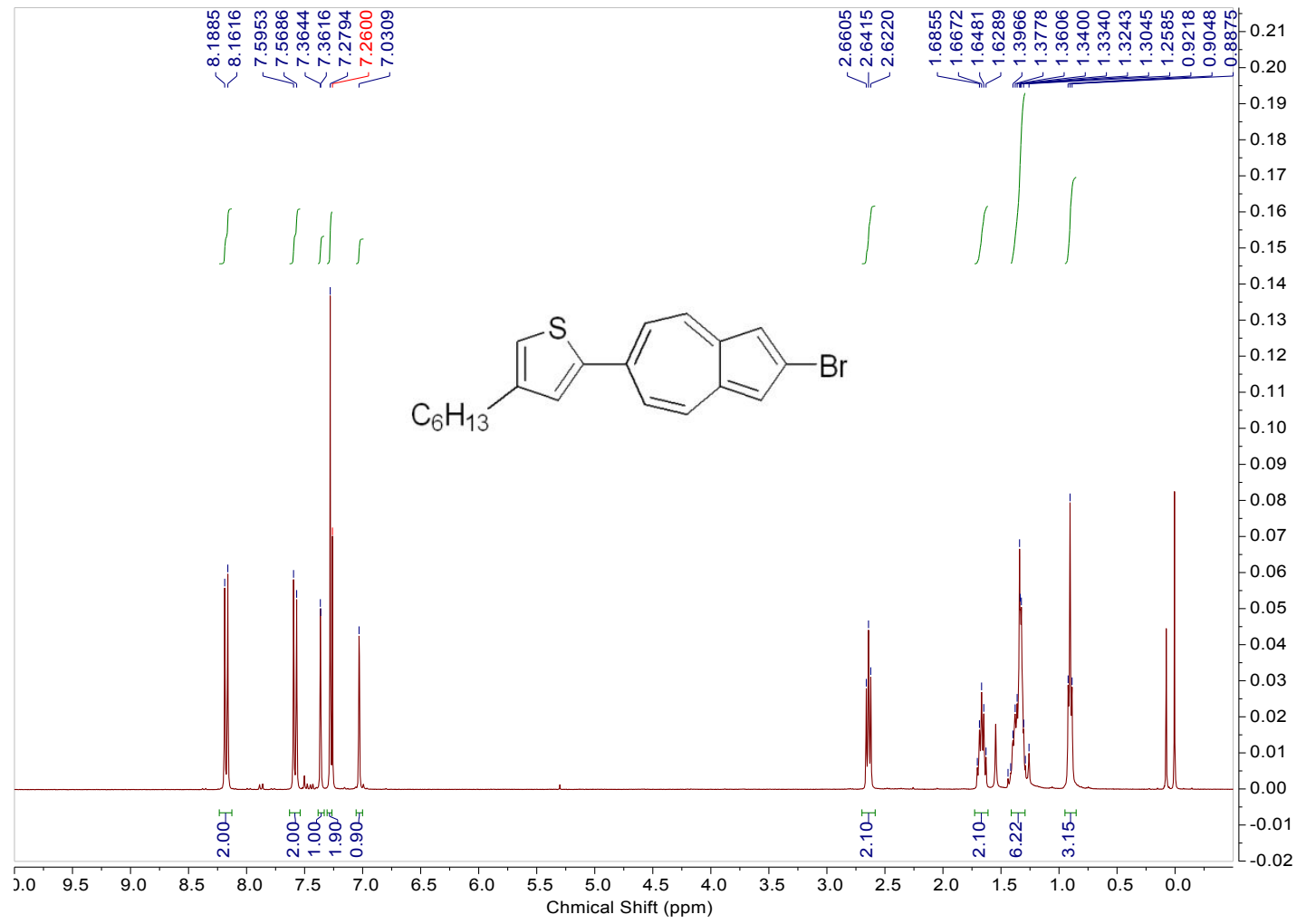

Figure S18. ${ }^{1} \mathrm{H}$ NMR spectrum of $4\left(\mathrm{CDCl}_{3}\right)$ 


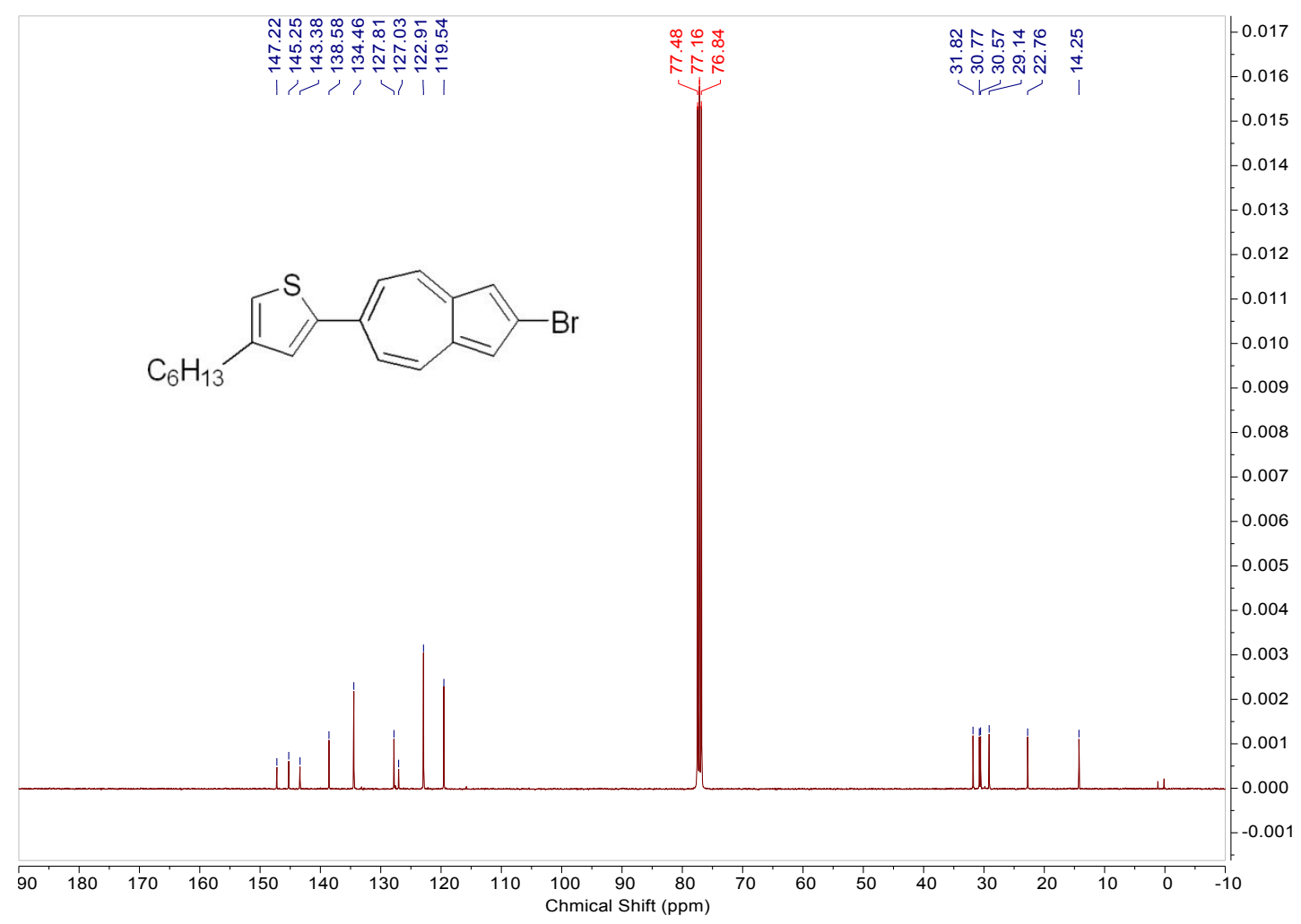

Figure S19. ${ }^{13} \mathrm{C}$ NMR spectrum of $4\left(\mathrm{CDCl}_{3}\right)$

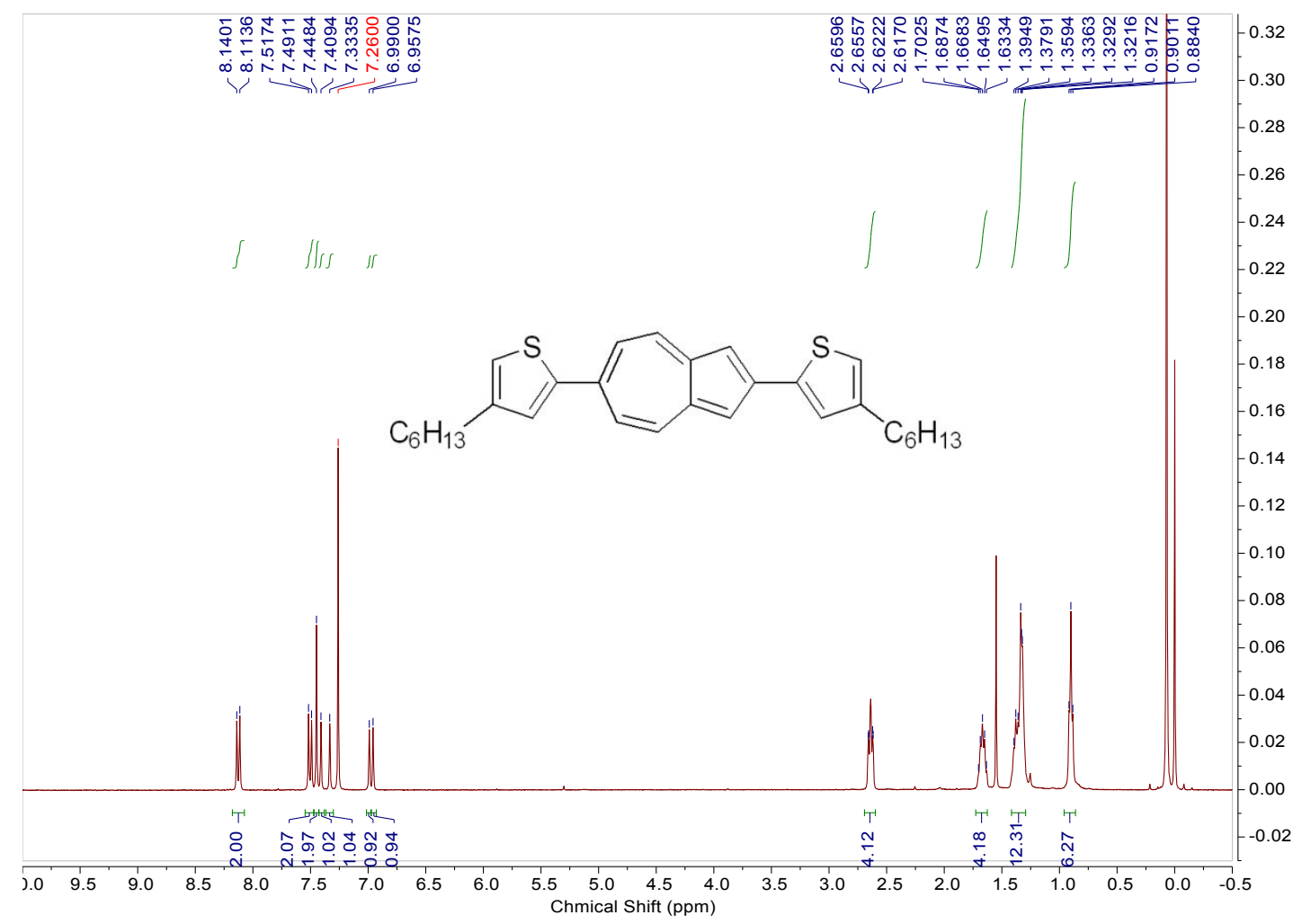

Figure S20. ${ }^{1} \mathrm{H}$ NMR spectrum of $5\left(\mathrm{CDCl}_{3}\right)$ 


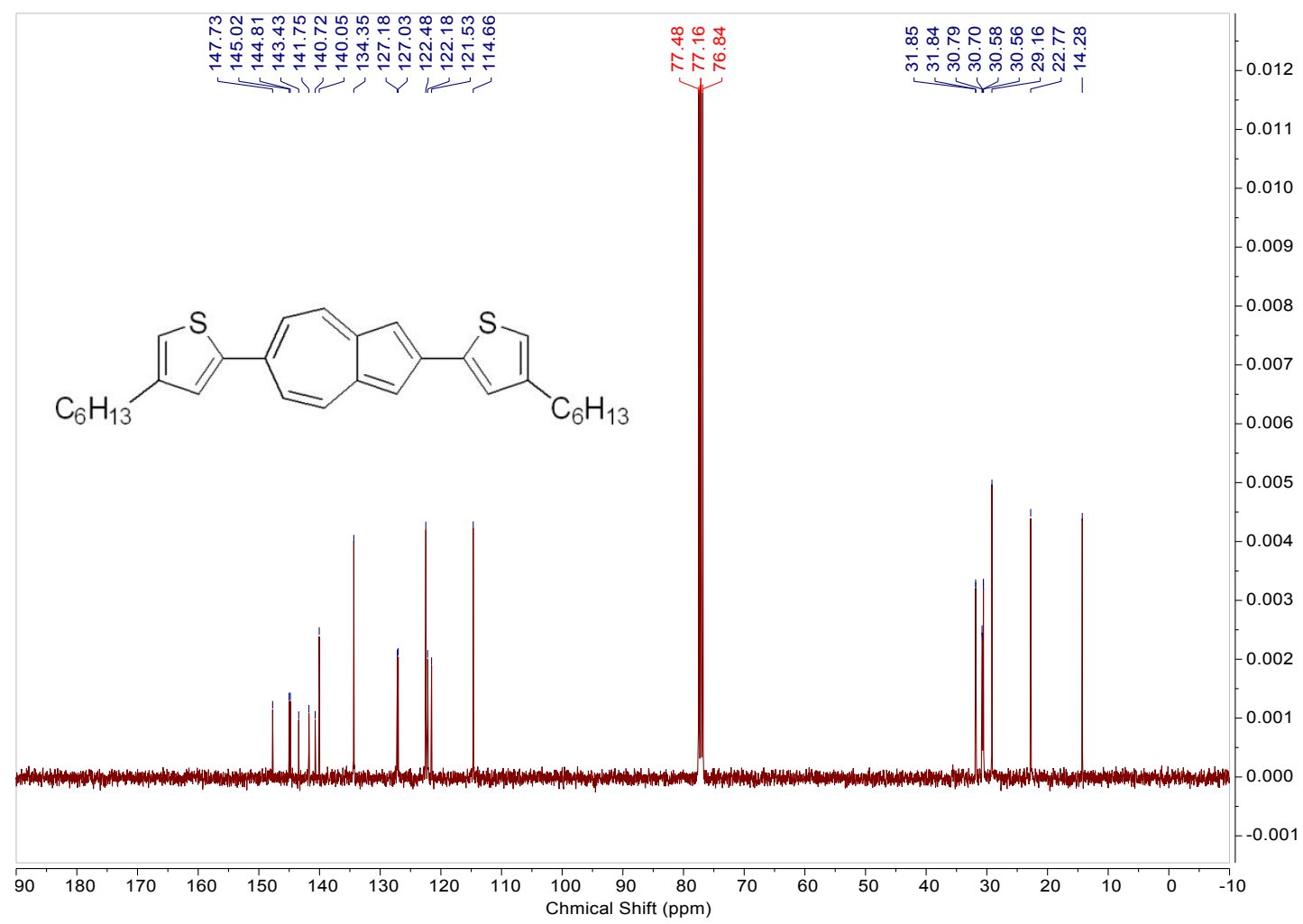

Figure S21. ${ }^{13} \mathrm{C}$ NMR spectrum of $5\left(\mathrm{CDCl}_{3}\right)$

\section{HRMS spectrum}

National Center for Organic Mass Spectrometry in Shanghai Shanghai Institute of Organic Chemistry

Chinese Academic of Sciences

High Resolution ESI-MS REPORT

Instrument: Thermo Scientific Q Exactive HF Orbitrap-FTMS

Card Serial Number: E212936

Sample Serial Number: 2020942-1-35-3

Operator: Songw Date: 2021/11/30

Operation Mode: ESI Positive Ion Mode

Elemental composition search on mass 373.0615

$\mathrm{m} / \mathrm{z}=368.0615-378.0615$

$\begin{array}{cccc}\mathrm{m} / \mathrm{z} & \text { Theo. } & \text { Delta } & \text { RDB } \\ \text { Mass } & (\mathrm{ppm}) \text { equiv. }\end{array}$

$\begin{array}{llll}373.0615 & 373.0620 & -1.31 & 9.5 \mathrm{C}_{20} \mathrm{H}_{22} \mathrm{Br} \mathrm{S}\end{array}$

Figure S22. HRMS of 4 
National Center for Organic Mass Spectrometry in Shanghai Shanghai Institute of Organic Chemistry

Chinese Academic of Sciences

High Resolution ESI-MS REPORT

Instrument: Thermo Scientific Q Exactive HF Orbitrap-FTMS

Card Serial Number: E212937

Sample Serial Number: $\quad 2020942-1-35-4$

Operator: Songw Date: 2021/11/30

Operation Mode: ESI Positive Ion Mode

Elemental composition search on mass 461.2324

$\mathrm{m} / \mathrm{z}=456.2324-466 \cdot 2324$

$\mathrm{m} / \mathrm{z}$ Theo. Delta RDB Composition

$\begin{array}{llll}461.2324 & 461.2331 & -1.45 & 12.5 \mathrm{C}_{30} \mathrm{H}_{37} \mathrm{~S}_{2}\end{array}$

Figure S23. HRMS of 5

\section{IR spectra}

Shanghai Institute of Organic Chemistry

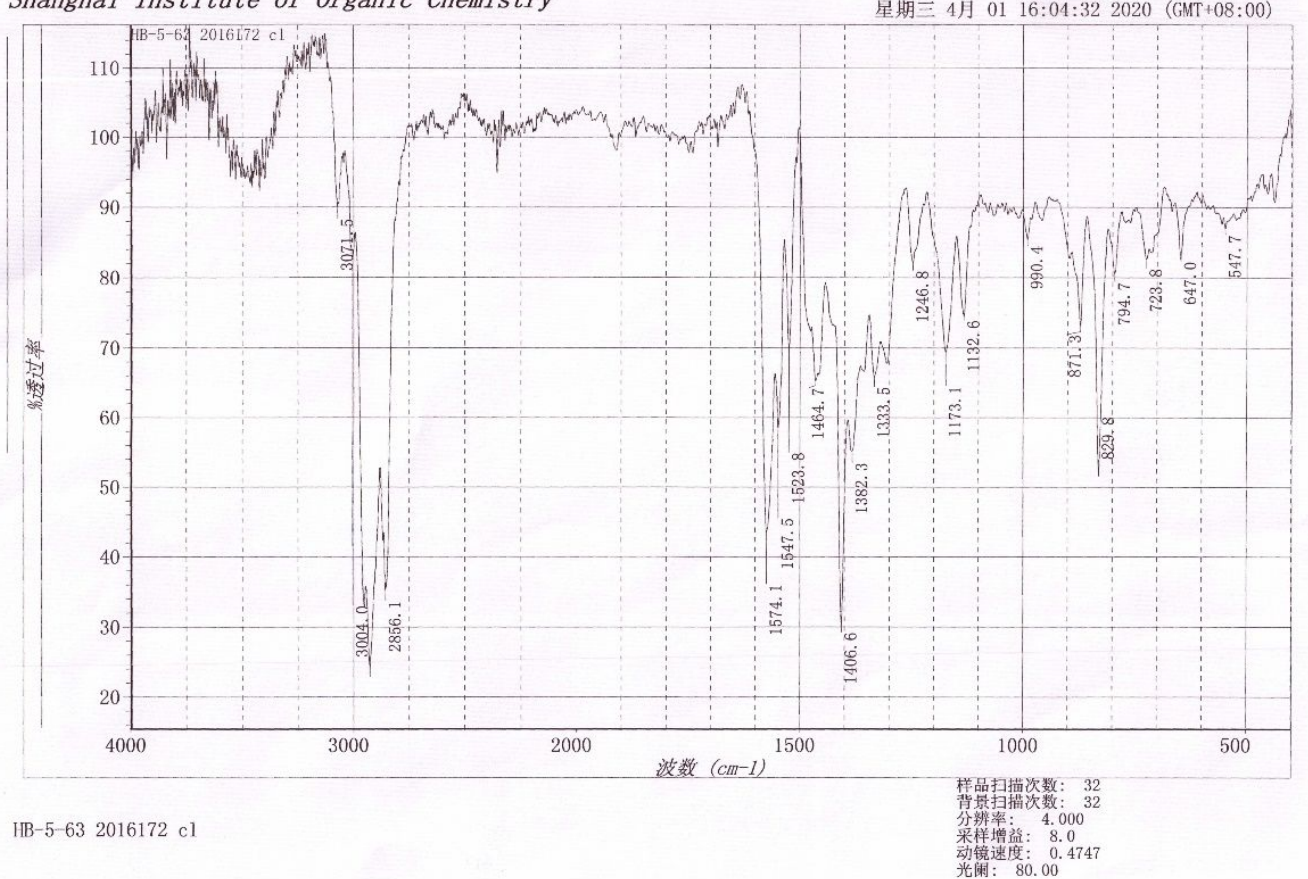

Figure S24. IR spectrum of P(AzIDT-C6) 
Shanghai Institute of Organic Chemistry

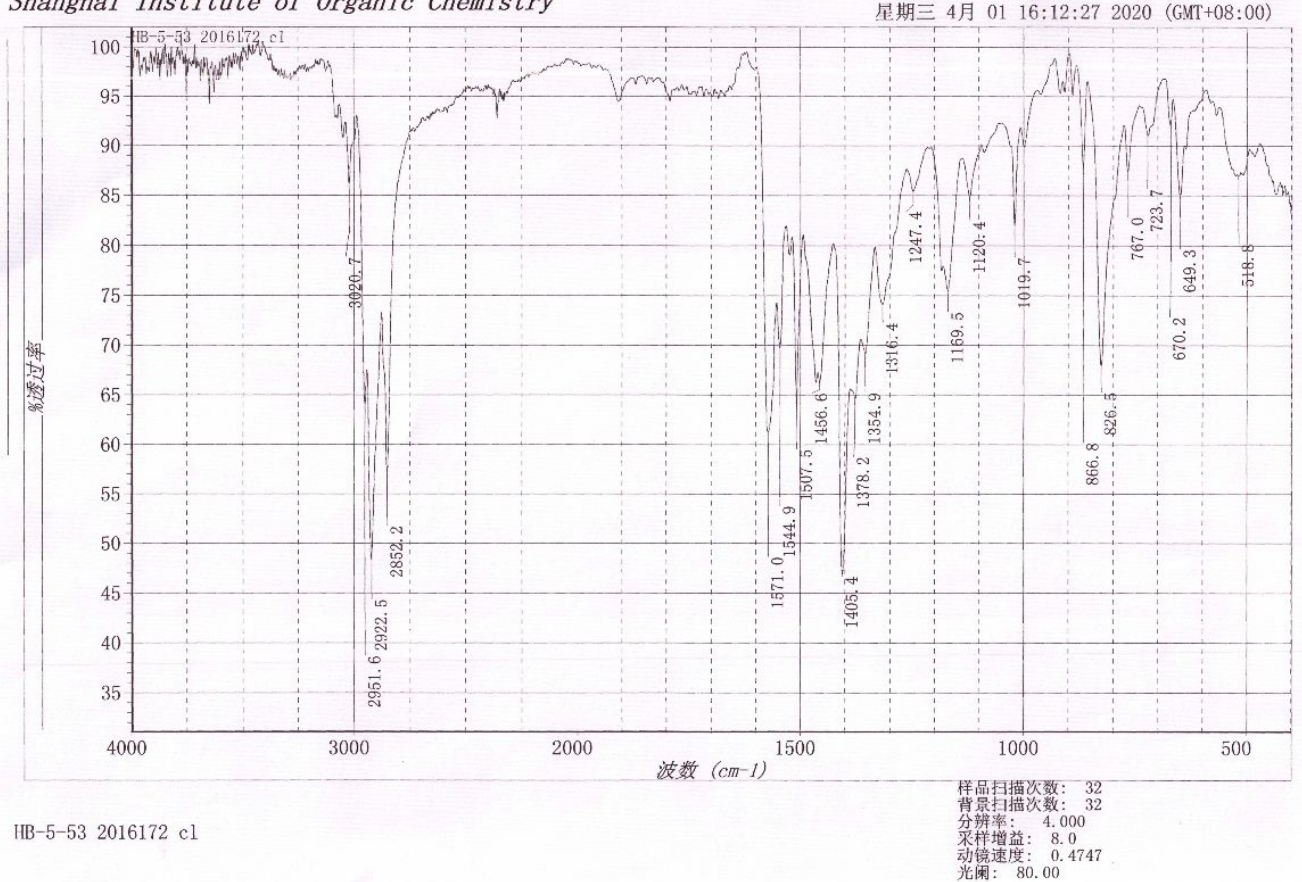

Figure S25. IR spectrum of P(AzIDT-PhC6)

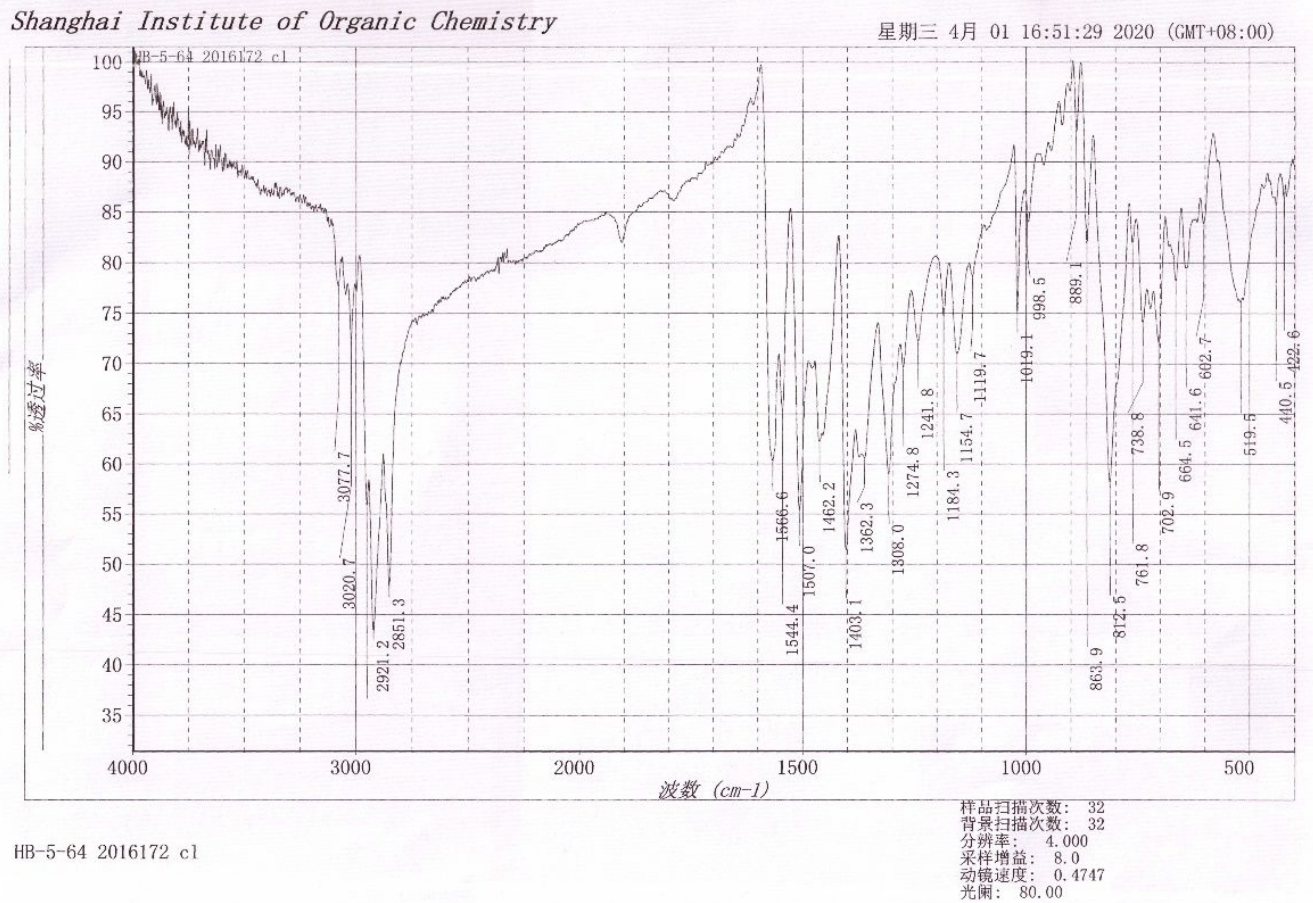

Figure S26. IR spectrum of P(AzIDTT-PhC6) 
Shanghai Institute of Organic Chemistry

星期三 12月 01 16:28:05 2021 (GMT+08:00)

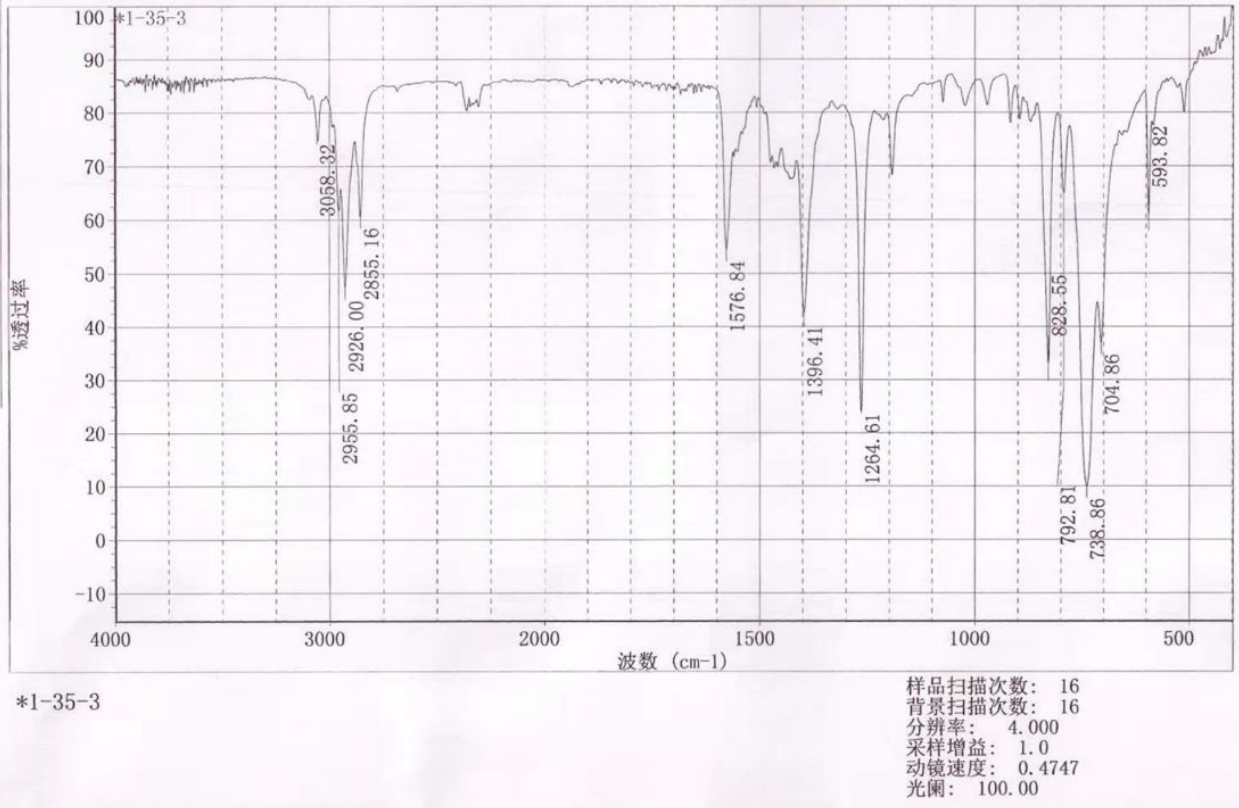

Figure S27. IR spectrum of $\mathbf{4}$

Shanghai Institute of Organic Chemistry

星期三 12月 01 16:33:15 2021 (GMT+08:00)

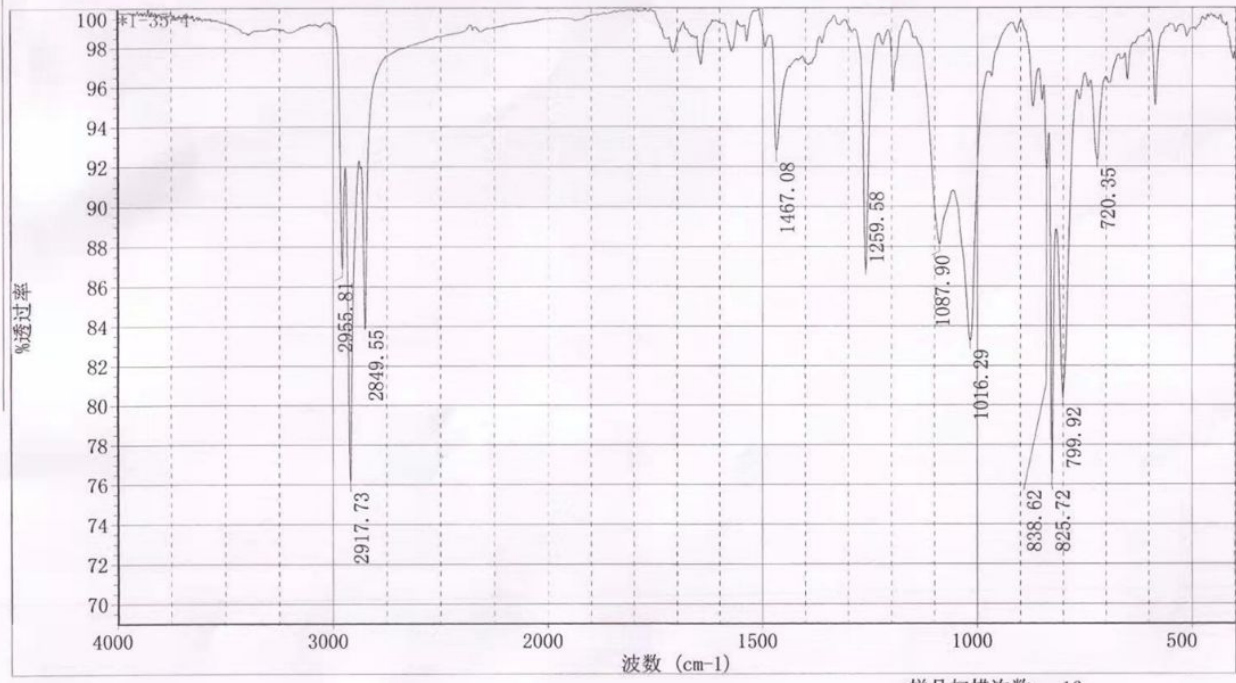

*1-35-4

样品扫描次数: 16

分辨率: 4.000

采样增益: 1.0

动锫速度: 0.4747

光阑: 100.00

Figure S28. IR spectrum of 5 


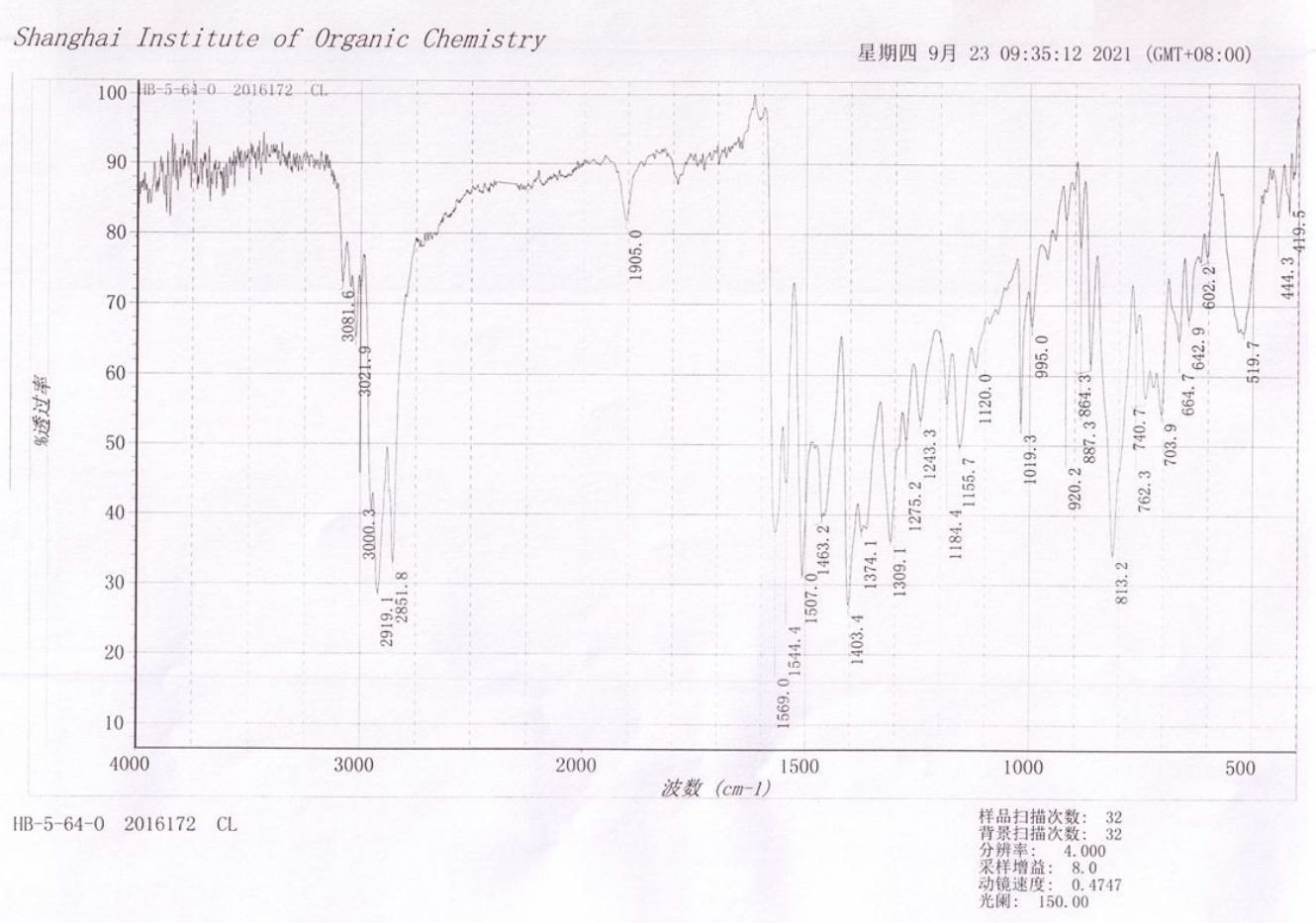

Figure S29. IR spectrum of P(AzIDTT-PhC6) after treating with 3\% (w/w) $\mathrm{H}_{2} \mathrm{O}_{2}$ aqueous solution and $1 \mathrm{M} \mathrm{H}_{2} \mathrm{SO}_{4}$

\section{References}

(1) Gao, H.; Ge, C.; Hou, B.; Xin, H.; Gao, X. Incorporation of 1,3-Free-2,6-Connected Azulene Units into the Backbone of Conjugated Polymers: Improving Proton Responsiveness and Electrical Conductivity. ACS Macro Lett. 2019, 8, 1360-1364.

(2) Schwarz, F.; Koch, M.; Kastlunger, G.; Berke, H.; Stadler, R.; Venkatesan, K.; Lörtscher, E. Charge Transport and Conductance Switching of Redox-Active Azulene Derivatives. Angew. Chem. Int. Ed. 2016, 55, 11781-11786.

(3) Frisch, M. J.; Trucks, G. W.; Schlegel, H. B.; Scuseria, G. E.; Robb, M. A.; Cheeseman, J. R.; Scalmani, G.; Barone, V.; Petersson, G. A.; Nakatsuji, H.; Li, X.; Caricato, M.; Marenich, A. V.; Bloino, J.; Janesko, B. G.; Gomperts, R.; Mennucci, B.; Hratchian, H. P.; Ortiz, J. V.; Izmaylov, A. F.; Sonnenberg, J. L.; Williams; Ding, F.; Lipparini, F.; Egidi, F.; Goings, J.; Peng, B.; Petrone, A.; Henderson, T.; Ranasinghe, D.; Zakrzewski, V. G.; Gao, J.; Rega, N.; Zheng, G.; Liang, W.; Hada, M.; Ehara, M.; Toyota, K.; Fukuda, R.; Hasegawa, J.; Ishida, M.; Nakajima, T.; Honda, Y.; Kitao, O.; Nakai, H.; Vreven, T.; Throssell, K.; Montgomery Jr., J. A.; Peralta, J. E.; Ogliaro, F.; Bearpark, M. J.; Heyd, J. J.; Brothers, E. N.; Kudin, K. N.; Staroverov, V. N.; Keith, T. A.; Kobayashi, R.; Normand, J.; 
Raghavachari, K.; Rendell, A. P.; Burant, J. C.; Iyengar, S. S.; Tomasi, J.; Cossi, M.; Millam, J. M.; Klene, M.; Adamo, C.; Cammi, R.; Ochterski, J. W.; Martin, R. L.; Morokuma, K.; Farkas, O.; Foresman, J. B.; Fox, D. J. Gaussian 16 Rev. B.01, Wallingford, CT, 2016.

(4) Kirby, N. M.; Mudie, S. T.; Hawley, A. M.; Cookson, D. J.; Mertens, H. D. T.; Cowieson, N.; Samardzic-Boban, V. A low-background-intensity focusing small-angle X-ray scattering undulator beamline. J. Appl. Crystallogr. 2013, 46, 1670-1680.

(5) Ilavsky, J. Nika: software for two-dimensional data reduction. J. Appl. Crystallogr. 2012, 45, 324328. 